Amasya Ilahiyat Dergisi - Amasya Theology Journal

ISSN 2667-7326 | e-ISSN 2667-6710

Aralık / December 2020, 15: 453-492

\title{
Osmanlı Vakıf Belgelerinde İmâm-1 Âzam Ebû Hanîfe ve Görüşleri: Makedonya Vakfiyeleri Örneği
}

\author{
Hasan TELLI \\ Dr. Öğr. Üyesi, Mersin Üniversitesi, İslami İlimler Fakültesi, \\ İslam Tarihi Anabilim Dalı \\ Assistant Professor, Mersin University, Faculty of Islamic Sciences, \\ Department of İslamic History \\ Mersin, Turkey \\ tellihasan@mersin.edu.tr \\ orcid.org/0000-0002-9142-7469
}

\section{Makale Bilgisi / Article Information}

Makale Türü / Article Types: Araştırma Makalesi / Research Article

Geliş Tarihi / Received: 11 Eylül / September 2020

Kabul Tarihi / Accepted: 21 Ekim / October 2020

Yayın Tarihi / Published: 30 Aralık / December 2020

Yayın Sezonu / Pub. Date Season: Aralık / December

Sayı / Issue: 15 Sayfa / Pages: 453-492

Atıf / Cite as: Telli, Hasan. "Osmanlı Vakıf Belgelerinde İmâm-ı Âzam Ebû Hanîfe ve Görüşleri: Makedonya Vakfiyeleri Örneği [Al-Imam al-A'zam Abu Hanifa and His Views in Ottoman Foundation Documents: Example of Macedonia Waqfiyyas]". Amasya Ilahiyat Dergisi-Amasya Theology Journal 15 (December 2020): 453-492.

https://doi.org/10.18498/amailad.793599.

Intihal / Plagiarism: Bu makale, en az iki hakem tarafından incelendi ve intihal içermediği teyit edildi. / This article has been reviewed by at least two referees and scanned via a plagiarism software.

Copyright (C) Published by Amasya Üniversitesi, İlahiyat Fakültesi / Amasya University, Faculty of Theology, Amasya, 05100 Turkey. All rights reserved. https://dergipark.org.tr/amailad. 
454 | H. TELLİ / Osmanlı Vakıf Belgelerinde İmâm-1 Âzam Ebû Hanîfe ve Görüşleri: Makedonya Vakfiyeleri Örneği

\section{Al-Imam al-A'zam Abu Hanifa and His Views in Ottoman Foundation Documents: Example of Macedonia Waqfiyyas}

\section{Absract}

The foundation establishment, which is established in the period of Prophet Muhammad, has started to become widespread in the Islamic society since the first years of Islam. Issues such as charity, ongoing charity, good deeds, selling their property to Allah, goodness, preferring your brother to your own soul, spend his wealth in the way of Allah, feeding, being in the way of Allah, gaining heaven and protection from hell, which are frequently mentioned in the Quran and the Sunnah of the Prophet Muhammad, have been the main factors that feed the spirit of the foundation. The foundation establishment completed its legal development in the second half of the third century of the Hijra and rapidly spread throughout the all Islamic territories where Muslims lived from Andalusia to Indonesia. Foundations were especially widespread in Seljuks and Ottoman Empire's period. Therefore, the term "Heaven of Foundations" was used for the Ottoman. In order to legally strengthen and to protect the foundations, legal foundation transactions called as "waqfiyya" were organized. This study concerns the case of how al-Imam al-A'zam and his views reflected on the waqfiyyas in the period of Ottoman Empire. The subject was restricted to the waqfiyya transactions that belong to the foundations that established in the Macedonian territory during the Ottoman period and which are currently under protection in the Archives of the General Directorate of Foundations in Turkey.

In 1389, the Ottomans defeated the Crusaders in the Battle of First Kosovo and dominated the territory of Macedonia. As in other territories in the Balqans that was conquered by Ottomans, the government provided foundation services in the region. In this sense, foundations were established in Macedonian cities such as Skopje, Debar, Doyran, Kriva Palanka, Gostivar, Štip, Tetovo, Kočani, Veles Kičevo, Kratovo, Kumanovo, Bitola, Ohrid, Prilep, Titveš and Strumica. These foundations have also undertaken important duties for the establishment of Turkish-Islamic culture in the region. Thanks to the foundations, monuments such as mosques, mosques, schools, madrasas, imarets, inns, baths, caravanserais, lodges, dervish lodges, hospitals, libraries, fountains, public fountains, bridges, tombs and Islamic cemeteries have been built in the heography of Macedonia. For the surviving and continuing of the services, fields, vineyards, gardens, plots, shops, lands and cash money were devoted. 
H. TELLİ / Al-Imam al-A'zam Abu Hanifa and His Views in Ottoman Foundation Documents: Example of Macedonia Waqfiyyas I 455

Waqfiyyas were organized for legal protection of foundation. Many of these waqfiyyas have been preserved until today. It was seen that some of these foundations refers the name of the founder of the Hanafi school, Imam alA'zam Abu Hanifa and his views. Apart from this, there is not any independent scientific study on Imam al-A'zam and his views in document of the Ottoman Foundation in the Ottoman period up today. For this reason, the issue of how the views of Imam al-A'zam were reflected in the Ottoman foundation documents has always remained as unclear. In this study, 164 foundations related to Macedonian waqfiyyas in the Archives of the General Directorate of Foundations were examined one by one and the waqfiyyas mentioning Imam al-A'zam are elaborated specifically.

In the light of Macedonian waqfiyyas, it was aimed to reveal the aspects of Imam al-A'zam and his views reflected in the Ottoman period foundation documents. In this sense, the issue of what kind of a Imam al-A'zam perception existed in the social imagination of the people who are involved in foundation services is examined. What kind of a Imam al-A'zam perception takes place in waqfiya transactions? How did the founders of foundation name and describe him? Why and for what purpose are Imam al-A'zam and his views included in the waqfiyyas? How are his views reflected on the waqfiyyas? Which opinions are included in the waqfiyyas? In what forms are these views expressed? Have his views are been acted or not? If not, what are the reasons behind it? How do the views of Imam al-A'zam relate to the recourse cases in the waqfiyyas? What is the significance and value of his views in Ottoman foundation practices? What are the Baktashi's perception of Imam al-A'zam in the waqfiyyas regarding Baktashi lodges? In the study, answers to such questions were sought and such issues were tried to be clarified in the light of documents.

The study is discussed under the headings of foundation definition, its authenticity, legal validity, real estate foundations, movable foundations and money foundations. The subject has been evaluated descriptively and systematically with archival reviews and induction method. The study has the first study feature in its field in terms of its specific subject. In this respect, it has a unique value.

Keywords: Islamic History, Ottoman, Al-Imam al-A'zam Abu Hanifa, Foundation, Macedonia. 
456 | H. TELLİ / Osmanlı Vakıf Belgelerinde İmâm-ı Âzam Ebû Hanîfe ve Görüşleri: Makedonya Vakfiyeleri Örneği

Osmanlı Vakıf Belgelerinde İmâm-ı Âzam Ebû Hanîfe ve Görüşleri: Makedonya Vakfiyeleri Örneği

\section{Öz}

Hz. Peygamber döneminde kurulan vakıf müessesesi, İslâm'ın ilk yıllarından itibaren İslâm toplumunda yaygınlaşmaya başlamıştır. Kur'ân-1 Kerim'de ve Hz. Peygamber'in sünnetinde sıkça geçen sadaka, sadaka-i câriye, salih amel, malını Allah'a satma, birr (iyilik), îsâr (kardeşini kendi nefsine tercih etme), infak, it'âm (yedirmek), sebilullah, cenneti kazanma ve cehennemden korunma gibi hususlar vakıf ruhunu besleyen ana unsurlar olmuştur. Vakıf müessesesi, hicri üçüncü asrın ikinci yarısında hukuki olarak gelişimini tamamlamış ve Endülüs'ten Endonezya'ya kadar Müslümanların yaşadığı tüm İslam coğrafyasında hızla yayılmıştır. Vakıflar özellikle Selçuklu ve Osmanlılarda yaygınlık göstermiştir. Bu yüzden Osmanlı toplumu için "Vakıflar Cenneti" tabiri kullanılmıştır. Vakıfları hukuki açıdan sağlamlaştırmak için vakfiye denilen hukuki vakıf senetleri düzenlenmiştir.

Bu çalışma İmâm-1 Âzam ve görüşlerinin Osmanlı dönemi vakfiyelerine nasıl yansıdığı konusunu içermektedir. Konu, Osmanlı döneminde Makedonya coğrafyasında kurulan vakıflara ait olan ve günümüzde Vakıflar Genel Müdürlüğü Arşivinde bulunan vakfiyeler kapsamında ele alınmıştır.

Osmanlılar, 1389 yılında I. Kosova Savaşı'nda Haçlı birliklerini yenerek Makedonya topraklarına hâkim olmuştur. Balkanlarda fethettiği diğger yerlerde olduğu gibi burada da vakıf hizmetleri sunmuştur. Bu anlamda Makedonya'nın Üsküp, Debre, Doyran, Eğri Palanka, Gostivar, İştip, Kalkandelen, Koçani, Köprülü, Kratova, Kumanova, Manastır, Ohri, Pirlepe, Tikveş ve Ustrumca gibi şehirlerinde vakıflar kurulmuştur. Bu vakıflar bölgede Türk-İslâm kültürünün yerleşmesi adına da önemli görevler üstlenmiştir. Vakıflar sayesinde Makedonya coğrafyasında camiler, mescitler, mektepler, medreseler, imaretler, hanlar, hamamlar, kervansaraylar, zaviyeler, tekkeler, hastaneler, kütüphaneler, çeşmeler, sebiller, köprüler, türbeler ve İslâm mezarlıkları gibi eserler yapılmıştır. Vakıf müesseselerinin ayakta kalması ve hizmetlerini devam ettirebilmesi için tarlalar, bağlar, bahçeler, arsalar, dükkânlar, araziler ve nakit paralar vakfedilmiştir.

Vakıfların hukuki olarak koruma altına alınması için vakfiyeler düzenlenmiştir. $\mathrm{Bu}$ vakfiyelerin birçoğu günümüze kadar korunmuştur. Bu vakfiyelerin bir kısmında Hanefi mezhebinin kurucusu İmâm-1 Âzam Ebû Hanîfe'ye ve görüşlerine yer verildiği görülmüştür. Bu zamana kadar Osmanlı dönemi vakfiye belgelerinde İmâm-1 Âzam ve görüşleri üzerinde müstakil herhangi bir 
H. TELLİ / Al-Imam al-A'zam Abu Hanifa and His Views in Ottoman Foundation Documents: Example of Macedonia Waqfiyyas I 457 bilimsel çalışma yapılmamıştır. Bu nedenle İmam-ı Âzam'ın görüşlerinin Osmanlı vakfiye belgelerine nasıl yansıdığı konusu hep muğlak kalmıştır. Bu çalışmada Vakıflar Genel Müdürlüğü Arşivi'nde bulunan Makedonya vakıflarıyla ilgili 164 vakfiye tek tek incelenmiş ve İmâm-1 Âzam'dan bahseden vakfiyeler üzerinde durulmuştur.

Makedonya vakfiyeleri 1şığında İmâm-1 Âzam ve görüşlerinin Osmanlı dönemi vakfiyelerine/vakıf belgelerine yansıyan yönlerinin ortaya çıkarılması amaçlanmıştır. Bu anlamda vakıf hizmetlerinde yer alan kişilerin zihin dünyasında nasıl bir İmâm-1 Âzam tasavvuru bulunduğu konusu irdelenmiştir. Vakfiyelerde nasıl bir İmâm-ı Âzam algısı vardır? Vakıf kurucuları onu nasıl isimlendirmiş ve ne şekilde vasıflandırmıştır? Vakfiyelerde İmâm-ı Âzam'a ve görüşlerine neden ve hangi amaçla yer verilmiştir? Onun görüşleri vakfiyelere nasıl yansımıştır? Vakfiyelerde hangi görüşlerine yer verilmiştir? Bunlar hangi formlarla ifade edilmiştir? Onun görüşleriyle amel edilmiş midir? Yoksa amel edilmemiş midir? Amel edilmediyse sebepleri nelerdir? İmâm-1 Âzam'ın görüşlerinin vakfiyelerdeki rücu davalarıyla nasıl bir ilgisi vardır? Onun görüşleri Osmanlı vakıf uygulamalarında nasıl bir önem ve değere sahiptir? Bektaşi tekkeleriyle ilgili vakfiyelerde Bektaşilerin İmâm-1 Âzam'la ilgili tasavvurları nasıldır? Çalışmada bunun gibi sorulara cevap aranmış ve bu gibi hususlar belgeler ışı̆̆ında aydınlatılmaya çalışılmıştır.

Çalışma vakfın tanımı, sıhhati, hukuki geçerliliği, gayrimenkul vakıflar, menkul vakıflar ve para vakıfları başlıkları altında ele alınmıştır. Konu deskriptif ve sistematik açıdan arşiv incelemeleri ve tümevarım yöntemiyle değerlendirilmiştir. Çalışma, spesifik konusu itibariyle alanında yapılan ilk çalışma özelliğine sahiptir. Bu yönüyle özgün değer taşımaktadır.

Anahtar Kelimeler: İslam Tarihi, Osmanlı, İmâm-1 Âzam Ebû Hanîfe, Vakıf, Makedonya.

\section{Giriş}

Hz. Peygamber döneminde kurulan vakıf müessesesi, ${ }^{1}$ İslâm'ın ilk yıllarından itibaren İslâm toplumunda yaygınlaşmaya başlamıştır. ${ }^{2}$

1 Sipahi Çataltepe, İslam-Türk Medeniyetinde Vakıflar (İstanbul: Türkiye Milli Kültür Vakfi Yayınları, 1991), 17.

2 Yasin Yılmaz, "Vakıf Kurumunun Dayandığı Temel Referanslar ve Zürrî Vakıfların Vakıf Sistemindeki Yeri", Dinî Araştırmalar, 17/44 (2014), 48-51. 
458 | H. TELLİ / Osmanlı Vakıf Belgelerinde İmâm-1 Âzam Ebû Hanîfe ve Görüşleri: Makedonya Vakfiyeleri Örneği

Sahabeden Câbir b. Abdullah, Medineli Müslümanlar arasında zengin olup da vakıf yapmayan kimsenin kalmadığını nakletmiştir. ${ }^{3}$ Kur'ân'da sıkça geçen sadaka, hayr, salih amel, malını Allah'a satma, birr (iyilik), îsâr (kardeşini kendi nefsine tercih etme), infak, it'âm (yedirmek), cenneti kazanma ve cehennemden korunma ${ }^{4}$ gibi hususlar vakıf ruhunu besleyen ana unsurlar olmuştur. "Allah'ın rizasına götüren yol" manasına gelen "sebîlullâh" terkibi, ${ }^{5}$ İslâm kültüründe Allah'ın rızasını kazanmak amaciyla, O'nun yolunda yapilan cihadi, mal ve can fedakârlığını ifade etmesinin yanında yol kenarlarında kuyular açmak, yolcuların konaklaması için hanlar inşa etmek gibi diğer insanların faydasına vakfedilen tüm müesseseleri ifade etmek için de kullanılmıştır. ${ }^{6} \mathrm{Bu}$ anlayışı temel alan vakıf müessesesi, hicri üçüncü asrın ikinci yarısında hukuki olarak gelişimini tamamlayarak, ${ }^{7}$ İslâm'ın dünyaya yayılmasıyla birlikte Endülüs'ten Endonezya'ya kadar Müslüman toplumların yaşadığı tüm İslâm coğrafyasında kendisini göstermiş ve onların iktisadî ve sosyal hayatı üzerinde derin tesirler bırakmıştır. ${ }^{8}$ Özellikle Selçuklu ve Osmanlılarda hayatın her sahasına nüfuz edecek kadar yaygınlaşmıştır. Bu yüzden Osmanlı toplumuna "Vakıflar Cenneti" tabiri kullanılmıştır. ${ }^{9}$ Osmanlı toplumunda gelişiminin zirvesine ulaşan vakıflar, dinî, siyasi, sosyal, kültürel ve ekonomik gibi her alanda topluma hizmetler sunmuş ve fethedilen topraklarda Türk-İslâm kültürünün yerleşmesi adına da önemli görevler

3 Hamdi Döndüren, "İslam'da Vakıf ve Güncel Değeri”, Keşkül Dergisi 38 (2016), 23.

4 Kur'an̂-ı Kerìm Meali, çev. Halil Altuntaş - Muzaffer Şahin (Ankara: Diyanet İşleri Başkanlığ Yayınları, 2011), el-Bakara 2/23-25, 195, 159, 261-276, Âl-i İmrân 3/107, 113 115, 130-131, 190-192, Nisâ 4/57, 124, Mâide 5/2, 48, 93, Tevbe 9/99, 111, Hûd 11/9-11, Ra'd 13/19-24, Kehf 18/1-3, Tâhâ 20/75-76, Mü'minûn 23/57-61, el-Haşr 59/9, İnsan 76/8-10, Ğâşiye 88/1-7, Beled 90/12-20; Muhammed Fuâd Abdülbâkî, el-Mu'cemü'l müfehres li elfâzi'l-Kur'âni'l-Kerîm (İstanbul: Çağrı Yayınları, 1987), 341-344.

5 İbrahim Yıldız, Kur'ân'da Sebîlüllah Kavramı (Bursa: Emin Yayınları, 2015), 74.

6 Yıldız, Kur'ân'da Sebîlüllah Kavramı, 33-34.

7 Adnan Ertem, “Osmanlıdan Günümüze Vakıflar”, Vakıflar Dergisi 36 (2011), 34.

8 H. Hüsnü Koyunoğlu, Sosyal Politika Açısından Vakıflar (İstanbul: İstanbul Üniversitesi, Sosyal Bilimler Enstitüsü, Doktora Tezi, 2002), 85; Fuat Köprülü, “Vakıf Müessesesinin Hukuki Mahiyeti ve Tarihi Tekâmülü", Vakıflar Dergisi, 2 (1942), 1.

9 Ertem, “Osmanlıdan Günümüze Vakıflar", 34; Ramazan Arslan, Erzurum Şehir Merkezindeki Vakıflar ve Sosyo-Ekonomik Bir Değerlendirme (Erzurum: Atatürk Üniversitesi, Sosyal Bilimler Enstitüsü, Yüksek Lisans Tezi, 1995), 11. 
H. TELLİ / Al-Imam al-A'zam Abu Hanifa and His Views in Ottoman Foundation Documents: Example of Macedonia Waqfiyyas | 459 üstlenmiştir. Osmanlı döneminde fethedilen topraklarda camiler, mescitler, mektepler, medreseler, imaretler, hanlar, hamamlar, kervansaraylar, zaviyeler, tekkeler, hastaneler, kütüphaneler, çeşmeler, sebiller, köprüler, türbeler ve İslâm mezarlıkları gibi müessesât-ı hayriye kabilinden hizmetler vakıflar eliyle yürütülmüştür. Bu müesseselerin ayakta kalması ve hizmetlerini idame ettirmesi adına tarlalar, bağlar, bahçeler, arsalar, dükkânlar ve araziler gibi gayrimenkuller ile nakit paralar vakfedilmiş ve bu mevkûfâttan elde edilen gelirler mezkûr vakıf müesseselerine tahsis edilmiştir. ${ }^{10}$ Osmanlı döneminde vakıf hizmetleri Devlet-i Aliyye'nin tüm topraklarında yaygınlık göstermiştir. Özellikle fethedilen Balkan topraklarında çok önemli vakıflar kurulmuştur. ${ }^{11}$

1371 yılında yapılan Çirmen Savaşı'nda Haçlı ittifakını yenerek Rumeli ve Batı Trakya'da ilerleyen Osmanlılar, 1382 yılında günümüz Makedonya topraklarında kalan İştip, Manastır ve Pirlepe'yi, ardından 1385 yılında Ohri'yi fethetmiştir. ${ }^{12} 1389$ yılında I. Kosova Savaşı'nda Haçlı birliklerini mağlubiyete uğratan Osmanlılar, ${ }^{13} 1390$ yılında Üsküp'ü fethederek Makedonya coğrafyasına hâkim olmuştur. ${ }^{14}$ Fetihten sonra vakıf hizmetleri Makedonya coğrafyasında hizla yayılmıştır. Makedonya'nın Üsküp, Debre, Doyran, Eğri Palanka, Gostivar, İştip, Kalkandelen, Koçani, Köprülü, Kratova, Kumanova, Manastır, Ohri, Pirlepe, Tikveş ve Ustrumca gibi şehirlerinde vakıflar

10 Yusuf Halaçoğlu, “Osmanlılarda Vakıf Müessesesi”, Vakıf Haftası Dergisi 1 (1984), 98; Yasin Yılmaz, Kanunî Vakfiyesi ve Süleymaniye Külliyesi (Ankara: Vakıflar Genel Müdürlüğü Yayınları, 2008), 29-31; Yasin Yılmaz - Hilal Aydemir, Erzurum Şeyhler Vakfı ve Külliyesi (Ankara: Semih Ofset, 2019), 26.

11 Hasan Telli, Osmanlı Dönemi Üsküp Vakıfları (Ankara: İlahiyat Yayınları, 2019), 16.

12 İsmail Hakkı Uzunçarşıll, Osmanlı Tarihi I (Ankara: TTK Yayınları, 1984), 161; Mehmet İnbaşı, "Balkanlar'da Osmanlı Hakimiyeti ve İskan Siyaseti”, Türkler, ed. Hasan Celal Güzel vd. (Ankara: Yeni Türkiye Yayınları, 2002), 9/282.

13 Halil İnalcık, Devlet-i Aliyye Osmanl İmparatorluğu Üzerine Araştırmalar-1 (İstanbul: Türkiye İş Bankası Kültür Yayınları, 2009), 87; Hüseyin Vehbi İmâmoğlu, Bir Dünya Devleti Osmanlı (1299-1922) (Samsun: Ceylan Ofset, 2008), 49.

14 Kosova Vilayeti Salnamesi, (Kosova: y.y., 1304), 170-171; Mehmet Hacisalihoğlu, "Makedonya", Türkiye Diyanet Vakfi İslâm Ansiklopedisi (Ankara: TDV Yayınları, 2003), 27/439. 
460 | H. TELLİ / Osmanlı Vakıf Belgelerinde İmâm-1 Âzam Ebû Hanîfe ve Görüşleri: Makedonya Vakfiyeleri Örneği

kurulmuş, bunlara ait vakfiyeler düzenlenmiş ve bu vakfiyelerin birçoğu günümüze kadar korunmuştur. ${ }^{15}$

Osmanlı döneminde vakfedilen bir malın hangi hayır işlerinde kullanılacağını ve ne şekilde yönetileceğini gösteren senet ${ }^{16}$ anlamına gelen vakfiyeler sayesinde vakıflar hukuki açıdan koruma ve kayıt altına alınmıştır. Bu vakfiyelerin bazılarında Hanefî mezhebinin kurucusu ve İslâm ilim ve düşünce tarihinin en önemli şahsiyetlerinden biri olan İmâm-1 Âzam Ebû Hanîfe'ye atıflarda bulunulmuş ve onun görüşlerine yer verilmiştir. ${ }^{17} \mathrm{Bu}$ zamana kadar Osmanlı vakıf belgelerinde İmâm-1 Âzam ve görüşleri üzerinde müstakil herhangi bir ilmî çalışma yapılmamıştır. Bu nedenle vakfiyelerde İmâm-ı Âzam'dan

15 BOA, AE.SABH.I.56-3994; BOA, AE.SABH.I.107-7308; BOA, A.DVNSMHM.D.85-439; BOA, A.DVNSHM.D.91-263; BOA, AE.SMST.II.9-806; BOA, AE.SMST.III.44-3155; BOA, AE.SSLM.III.34-1949; BOA, E.SMMD.IV.81-9616; BOA, DH.ID.16-43; BOA, C.BLD.18-851; BOA, C.EV.63-3145; BOA, C.EV. 67-3335; BOA, C.EV.66-3282; BOA, C.EV.120-5983; BOA, C.EV.85-4207; BOA, C.EV.251-12641; BOA, C.EV.69-3426; BOA, C.EV.461-23309; BOA, C.EV.50-2452; BOA, C.EV.132-6581; BOA, C.EV.118-5885; BOA, EV.BRT.1-16; BOA, EV.BRT.5-13; BOA, EV.BRT.41-13; BOA, EV.BT.143-10; BOA, EV.BRT.199-23; BOA, EV.BRT.212-9; BOA, EV.D.14487; BOA, İE.EV.21-2529; BOA, HR.SFR.04..710-59; BOA, İ.ŞD.68-3984; BOA, İ.EV.55-23; BOA, İ.ML.91-29; BOA, MVL.467-90, BOA, MVL.472-21; BOA, TFR.I.MN.185-18410; BOA, TFR.I.ŞKT.64-6389; BOA， TFR.I.ŞKT.119-11843; BOA， TFR.I.ŞKT.47-4625; BOA, TFR.I.ŞKT.16-1507; BOA, Y.A.RES.94-21; BOA, HAT.1604-68; BOA, TFR.I.KV.75-7425; BOA, TFR.I.KV.133-13228; BOA, İÇMMS.20-890; VGMA, Defter 629/415332; VGMA, Defter 988/286/184; VGMA, Defter 603/179/302; VGMA, Defter 607/44/65; VGMA, Defter 988/142/56; VGMA, Defter 990/53/47; VGMA, Defter 987/274/95; VGMA, Defter 991/59/76; VGMA, Defter 989/234/185; VGMA, Defter 601/155/199; VGMA, Defter 582-2/503/376; VGMA, Defter 990/74/62; VGMA, Defter 990/3/3; VGMA, Defter 989/50/39; VGMA, Defter 989/235/186; VGMA, Defter 990/48/39; VGMA, Defter 632/424/194; VGMA, Defter 633/21/11; VGMA, Defter, 991/53/70; VGMA, Defter, 633/348/123; VGMA, Defter 988/142/56; VGMA, Defter 988/237/144; VGMA, Defter 989/164/122; VGMA, Defter 989/235/186; VGMA, Defter 991/45/57; VGMA, Defter 991/33/37; VGMA, Defter 991/58/75; VGMA, Defter 989/180/137; VGMA, Defter 989/185/141; VGMA, Defter 631/25/10; VGMA, Defter 989/167/126; Başbakanlık Osmanlı Arşivi Daire Başkanlığı (BOA), Makedonya'daki Osmanlı Evrakı (Ankara: Osmanlı Arşivi Daire Başkanlı̆̆ 1 Yayınları, 1996), 34-48.

16 Osman Gazi Özgüdenli, “Vakfiye”, Türkiye Diyanet Vakfı İslâm Ansiklopedisi (İstanbul: TDV Yayınları, 2012), 42/465.

17 Eyüp Akdağ, "Ebû Hanîfe'nin (ö. 150/767) Hayatı ve Zühd Anlayışı”, Amasya Üniversitesi İlahiyat Fakültesi Dergisi 11 (2018), 169. 
H. TELLİ / Al-Imam al-A'zam Abu Hanifa and His Views in Ottoman Foundation Documents: Example of Macedonia Waqfiyyas | 461 ve onun görüşlerinden kimin/kimlerin neden ve nasıl bahsettiği konusu hep muğlak kalmıştır. Bu çalışmada Vakıflar Genel Müdürlüğü Arşivinde yer alan Makedonya vakfiyeleri esas alınarak İmâm-1 Âzam ve görüşleri üzerinde durulmuştur. Çalışmada öncellikle vakıf hizmetlerinde yer alan vâkıf, mütevelli, kâtip ve kadı gibi şahsiyetlerin İmâm-1 Âzam hakkındaki tasavvurlarının ne olduğu, onu nasıl isimlendirdikleri ve ne surette vasıflandırdıkları üzerinde durulmuştur. Devaminda Makedonya vakfiyeleri esas alınarak vakfiyelerde İmâm-1 Âzam'a ve görüşlerine neden yer verildiği hususu irdelenmiştir. Son olarak da hangi vakfiyelerde İmâm-1 Âzam'ın hangi görüşlerine yer verildiği, bu görüşlerle amel edilip edilmediği, Osmanlı tatbikatında vakıf hizmetlerinin idamesi açısından İmâm-1 Azâm'1n görüşlerinin anlam ve değerinin ne olduğu hususları belgeler 1şı̆̆ında incelenmiş ve ortaya konmaya çalışılmıştır.

\section{Vakfiyelerde İmâm-ı Âzam'ın İsimleri ve Vasıfları}

Vakıflar Genel Müdürlüğü Arşivinde yer alan Makedonya vakfiyelerinin birçoğunda vâkıf, mütevelli, kâtip ve kadı gibi vakıf hizmetlerinin içerisinde bulunan bazı görevlilerin İmâm-1 Âzam'a ve görüşlerine yer verdiği görülmektedir. Buna göre söz konusu vakfiyelerde onun ismi genellikle "İmām-ı A'ẓam” veya "İmām-1 A ‘ẓam Ebū Haniffe" olarak geçmektedir. Bu, onun geleneksel kullanılan ismine uygun olduğunu da göstermektedir. Vakfiyelerde isminin yanı sıra İmâm-1 Âzam'ın ilmî, ictihadî ve ahlakî alandaki çeşitli vasıflarına değinilmiş ve özellikle İslâm toplumundaki konumu, yeri ve değeri ile ilgili özelliklerine vurgu yapılmıştır. Kûfeli olduğuna dikkat çekilmiş ve onun için hayır dualarda bulunulmuştur. ${ }^{18}$

18 VGMA, Defter 629/415332; VGMA, Defter 988/286/184; VGMA, Defter 603/179/302; VGMA, Defter 607/44/65; VGMA, Defter 988/142/56; VGMA, Defter 990/53/47; VGMA, Defter 987/274/95; VGMA, Defter 991/59/76; VGMA, Defter 989/234/185; VGMA, Defter 601/155/199; VGMA, Defter 582-2/503/376; VGMA, Defter 990/74/62; VGMA, Defter 990/3/3; VGMA, Defter 989/50/39; VGMA, Defter 989/235/186; VGMA, Defter 990/48/39; VGMA, Defter 632/424/194; VGMA, Defter 633/21/11; VGMA, Defter, 991/53/70; VGMA, Defter, 633/348/123; VGMA, Defter 988/142/56; VGMA, Defter 988/237/144; VGMA, Defter 989/164/122; VGMA, Defter 989/235/186; VGMA, Defter 991/45/57; VGMA, Defter 991/33/37; VGMA, Defter 991/58/75; VGMA, Defter 989/180/137; VGMA, Defter 989/185/141; VGMA, Defter 631/25/10; VGMA, Defter 989/167/126; Ahmet Ak, “İmâm-1 Azâm Ebû Hanife'nin Hayatı ve İtikadî Görüşleri”, 
462 | H. TELLİ / Osmanlı Vakıf Belgelerinde İmâm-1 Âzam Ebû Hanîfe ve Görüşleri: Makedonya Vakfiyeleri Örneği

Konuyla ilgili incelenen vakfiyelerde İmâm-1 Âzam'ın bizzat kendisi kastedilerek onun için kullanılan ve ön plana çıkartılan çeşitli isim ve vasıflarını şu şekilde sıralamak mümkündür:

a. İmām-1 A żam

b. Ebū Ḥanīfe

c. Müctehid-i akdem

ç. el-Kūfī

d. Hümām-1 efham

e. Hümām-1 aḳdem

f. İmām hümām-1 ekrem

g. Kāşifü'l-gam

ğ. Sirāc-1 ümmet

h. Sirācü'l-milleti ve'd-dīn

1. Sirācü'l-eimme

i. Sulțān-1 serīr-i ictihād

j. Melikil-mülkil-hidāyet ve'r-reşād

k. Pişuvā-yı kül reh-nümā-yı sübül

Hanefî mezhebinin kurucusu Ebû Hanîfe'den bahseden tüm vakfiyelerde onun ismi "Büyük İmâm" anlamında "İmām-1 A'ẓam" olarak anılmış ve İmâm-1 Âzam ismine mutlaka yer verilmiştir. Üsküp'teki Şâfizâde Seyyid Sadi Efendi Vakfı'nda olduğu gibi onun ismi bazen sadece "İmām-1 A'z̧am" olarak geçmiş19 bazen de Üsküp'teki Belkıs Hanım binti Mahmud Pertev Paşa Vakfı'nda olduğu gibi “İmām-ı A'ẓam ve hümām-1 efham Ebū Hanīfeti'l-Kūfî Hażretleri" şeklinde daha uzun tanımlamalarla yer almıştır. ${ }^{20}$ Ebû Hanîfe'nin "İmâm-1 Âzam" olarak şöhret bulan bu ismi ${ }^{21}$ vakfiyelerde de kendini göstermiştir.

Kumanova'da Süleyman A ğa bin Mahmud, ${ }^{22}$ Üsküp'te Nureddin bin Osman $^{23}$ ve Ayşe Hanım binti Mehmed $^{24}$ gibi vakıfların

KSÜ İlahiyat Fakültesi Dergisi, 27 (2016), 3; Murtaza Köse, “Büyük Üstad Ebû Hanîfe”, Ağrı İbrahim Çeçen Üniversitesi Sosyal Bilimler Enstitüsü Dergisi 1/1 (2015), 161.

19 VGMA, Defter 989/185/141.

20 VGMA, Defter 990/74/62.

21 Mustafa Uzunpostalcı, "Ebû Hanîfe", Türkiye Diyanet Vakfı İslâm Ansiklopedisi (İstanbul: TDV Yayınları, 1994), 10/131.

22 VGMA, Defter 989/226/179.

23 VGMA, Defter 991/45/57.

24 VGMA, Defter 989/234/185. 
vakfiyelerinde "Ebû Haniffe" ismi kullanılmıştır. Bu da zaten İmâm-1 Âzam'ın en yaygın kullanılan künyesidir. ${ }^{25}$

İştip'te Timur A ğa Vakfı, ${ }^{26}$ Üsküp'te Sabri Efendi bin Şeyh İdris Vakf1, ${ }^{27}$ Doyran'da Hatice Hatun Vakf1 ${ }^{28}$ ve Debre'de Hatib Ağa bin İbrahim Vakfı gibi birçok vakfın vakfiyesinde İmâm-1 Âzam için "Ḥażretleri" ifadesinin kullanıldığı ve onun sayg1 ve hürmetle anıldığ görülmüştür. Üsküp'te Yahya Paşa Vakfı'nın ve Rifâiyye tarikatından Şeyh Mehmed Efendi bin İsmail Vakfı'nın vakfiyesinde ise İmâm-ı Âzam'ın isminin ardından "radiyallahu 'anhu"29 (Allah ondan razı olsun) denildiği ve ona hayır duada bulunulduğu tespit edilmiştir.

Üsküp'te Güherçile Emini İbrahim Bey Vakfı'nın vakfiyesinde İmâm-1 Âzam için "Ḥażreti İmām-1 Aẓam ve müctehid-i aḳdem"30 ifadesi kullanılmıştır. Bununla da İmâm-ı Âzam'ın en kadim/eski ve en mühim müçtehitlerden biri olduğuna vurgu yapılmıştır.

İştip'te Timur Ağa Vakfı, ${ }^{31}$ Manastır'da Besim Paşa bin Osman Bey Vakf1, ${ }^{32}$ Mustafa Nuri Bey Vakf1, ${ }^{33}$ Üsküp'te Mehmed Faik Paşa Vakf1, ${ }^{34}$ Abdulbaki Efendi Vakf1, ${ }^{35}$ Atiyye Hanım binti Arslan Bey Vakf1, ${ }^{36}$ Ayşe Hanım binti Mehmed Efendi Vakf1 ${ }^{37}$ ve Hüseyin Bey bin Süleyman $\mathrm{Vakf1}^{38}$ gibi vakıfların vakfiyelerinde İmâm-1 Âzam için "hümām-1 efham", "hümām-1 ekrem" ve "el-Kūfî"39 vasıflandırmaları

25 Hacısalihoğlu, “Makedonya”, 27/439.

26 VGMA, Defter 604/138/183.

27 VGMA, Defter 989/180/137.

28 VGMA, Defter 609/253/305.

29 VGMA, Defter 629/415/332.

30 VGMA, Defter 630/1338/816.

31 VGMA, Defter 604/138/183.

32 VGMA, Defter 987/199/63.

33 VGMA, Defter 989/150/114.

34 VGMA, Defter 988/237/144.

35 VGMA, Defter 988/286/184.

36 VGMA, Defter 991/59/76.

37 VGMA, Defter 989/234/185.

38 VGMA, Defter 990/48/39.

39 "Hümâm"; Bir işi başarmak için çaba gösteren, himmeti ve gayreti çok olan kimse, "Efham"; kadri pek yüce, pek ulu, çok şerefli, çok değerli, "ekrem"; çok kerim, cömert, lütuf ve kerem sahibi anlamlarına gelmektedir. Kubbeatlı Akademisi Kültür ve Sanat Vakfı, Kubbealtı Lugatı, (Erişim 27 Mayıs 2020). “el-Kûfî” ise İmâm-1 Âzam’ın Kûfeli olduğunu ifade etmektedir. 
464 | H. TELLİ / Osmanlı Vakıf Belgelerinde İmâm-1 Âzam Ebû Hanîfe ve Görüşleri: Makedonya Vakfiyeleri Örneği

kullanılmıştır. Bu vasıflandırmalar, vâkıfların nazarıyla İmâm-ı Âzam'ın lütuf sahibi cömert bir şahsiyet olduğunu ve İslâm toplumu nezdindeki değerinin ve kadrinin pek yüce ve pek şerefli olduğunu ortaya çıkarmaktadır.

Manastır'da Rifâî tarikatından Seyyid Mehmed Nazmi Efendi bin Seyyid Abdurrahman Efendi Vakfı'nın ${ }^{40}$ ve Gostivar'da ashâb-1 hayrâttan ve Halveti tarikatı meşâyihinden Şeyh Nuh Efendi Vakfı'nın vakfiyesinde İmâm-1 Âzam "Hümām-1 aḳdem", 41 "Sirāc-1 ümmet"42 ve "Kāşifü'l-gam" ${ }^{43}$ olarak tavsif edilmiştir. ${ }^{44} \mathrm{Bu}$ da İmâm-1 Âzam'ın verdiği fetvalar ve yaptığı içtihatlarla İslâm toplumunu aydınlatan, onun sıkıntılarını gideren ve dertlerine derman olan bir şahsiyet olarak değerlendirildiğini göstermektedir.

Kalkandelen civarında ve Serlar-1 Bâlâ, Serlar-1 Zîr, Teber, Şetân, Boltice, Kubanice, Selçe-i Kebir, Lebyân ve Leşka köylerinde sahip olduğu emlâk, koru, tarla, çayır, bağ ve bahçelerini Kalkandelen'deki Bektaşî Harabatî Baba Tekkesi denilen Sersem Ali Baba Zaviyesi'nin meşihat ciheti, tamiri ve zaviyede yemek yedirilmesi gibi ihtiyaçları için vakfeden Recep Paşa, 10 Şevval 1204/23 Haziran 1790 tarihli vakfiyesinde İmâm-1 Âzam için "Hümām-1 aḳdem Sirācü'l-eimme Hażretleri" tabirini kullanmıştır. Recep Paşa bu ifadeleriyle İmâm-1 Âzam'ın ümmetin kandili olduğunu, en kadim, en büyük ve en civanmert bir âlim olduğunu dile getirmiştir. ${ }^{45} \mathrm{Bu}$ ifadeler 18. yüzyıl sonlarında bir Bektaşî tekkesi kültüründe nasıl bir İmâm-ı Âzam tasavvuru bulunduğunu göstermesi açısından da çok önemlidir.

Manastır'da Faik Paşa Vakf1 ${ }^{46}$ ve Üsküp'teki Mehmed Paşa Vakfı'nın vakfiyesinde İmâm-1 Âzam, milletin ve dinin aydınlatıcı kandili anlamina gelen "sirācü'l-milleti ve'd-dīn" diye tavsif edilmiştir. $\mathrm{Bu}$ vasıflandırma, onun ilmî ve dinî şahsiyetinin ve hizmetlerinin Müslümanlar nezdinde ne kadar muteber görüldügüüe da işaret etmektedir.

\footnotetext{
40 VGMA, Defter 583/146/129.

41 En eski, en gayretli, civanmert, büyük âlim demektir.

42 Ümmetin nur saçan kandili anlamına gelmektedir.

43 Derdi/gammı ortadan kaldıran demektir.

44 VGMA, Defter 629/736/489.

45 VGMA, Defter 929/3/3.

46 VGMA, Defter 989/63/51.
} 
H. TELLİ / Al-Imam al-A'zam Abu Hanifa and His Views in Ottoman Foundation Documents: Example of Macedonia Waqfiyyas | 465

Koçani'de bir medrese yaptıran ve sahip olduğu dükkânlarını bu medreseye vakfeden Hasan Bey, 11 Rebiü'l-evvel 1235/28 Aralık 1819 tarihli vakfiyesinde İmâm-1 Âzam için "Ṣulțān-1 serīr-i ictihād Hażreti İmām-1 A'ẓam" ifadesini kullanmış ve onun içtihat makamının sultanı olduğunu ön plana çıkarmıştır. ${ }^{47}$ Üsküp'te Muhyiddin Efendi Vakfı'nın vakfiyesinde İmâm-1 Âzam için "Ṣulțān-1 serīr-i ictihād ve melikilmülkil-hidāyet ve'r-reşād ve pişuvā-yı kül reh-nümā-yı sübül" 48 ifadesi kullanılmıştır. Bu ifadelerle onun içtihat saltanatının sultanı, hidayet ve doğru yolu bulmada söz sahibi bir melik, herkesin ittiba ettiği bir imam ve doğru yolu gösteren bir rehber olduğu ifade edilmiştir.

Bazı vakfiyelerde İmâm-1 Âzam'ın da dâhil olduğu âlimler için birçok vasıflandırmalar yapılmıştır. Bunları şu şekilde ifade edebiliriz.
a. Eimme-i kibâr
b. Eimme-i kirâm
c. Eimme-i selâse
ç. Eimme-i dîn
d. Eimmetü'l-eslâf
e. Eimme-i Hanefiyye
f. Eimme-i müctehidin
g. Eimmetü'l-eşrâf

İmâm-1 Âzam'ın da içinde olduğu Hanefî fıkıh âlimleri için Üsküp'te Güherçile Emini İbrahim Bey Vakfı'nın vakfiyesinde "eimme-i kibâr" yani büyük imamlar/âlimler, ${ }^{49}$ Manastır'da Hacı Halil Ağa bin Hacı Mustafa Vakfı'nın ${ }^{50}$ ve Üsküp'te Abdullah bin Hüseyin Vakfı'nın vakfiyesinde "eimme-i kirâm" yani değerli imamlar,51 Manastır'da Hasan Ağa Vakfı, ${ }^{52}$ Debre'de Hatib Ağa bin İbrahim Vakf1, ${ }^{53}$ Üsküp'teki Bayram bin Zeynel Vakf1, ${ }^{54}$ Osman bin Latif Vakf1 ${ }^{55}$ ve Nureddin bin Osman Vakfı'nın ${ }^{56}$ vakfiyelerinde "eimme-i selâse" yani Hanefî

\footnotetext{
47 VGMA, Defter 989/170/127.

48 VGMA, Defter 990/3/3.

49 VGMA, Defter 630/1338/816.

50 VGMA, Defter 987/94/22.

51 VGMA, Defter 603/179/302.

52 VGMA, Defter 652-2/615/653.

53 VGMA, Defter 604/146/197.

54 VGMA, Defter 601/155/199.

55 VGMA, Defter 991/33/37.

56 VGMA, Defter 991/45/57.
} 
466 | H. TELLİ / Osmanlı Vakıf Belgelerinde İmâm-1 Âzam Ebû Hanîfe ve Görüşleri: Makedonya Vakfiyeleri Örneği

mezhebinin üç büyük imamı, Kalkandelen'de İlyas Ağa bin İsmail ${ }^{57}$ ve Kamil bin Zeynel ile Üsküp'te Memiş bin Osman ve Faruk bin Bahaeddin gibi birçok vakfın vakfiyesinde "eimme-i dîn" yani din imamları, ${ }^{58}$ Üsküp'te Ahmed Ağa bin Hacı Hasan Vakfı, Mehmed Ali Bey Vakfı, Ramiz Bey bin Hasan Vakfı, ${ }^{59}$ Mehmed Faik Paşa Vakfı ve Sabri Efendi Vakfı'nın vakfiyesinde "eimmetü'l-eslâf" yani daha önceki imamlar, ${ }^{60}$ Üsküp'te Kaçanikli Mehmed Paşa Vakfı'nın vakfiyesinde "eimme-i Hanefiyye" yani Hanefi mezhebinin önde gelen imamları/âlimleri, ${ }^{61}$ Gostivar'da Emin Ağa bin Seydullah Vakf1, ${ }^{62}$ Üsküp'te Abdulbaki Efendi Vakfı, Şafi' izâde Seyyid Sadi Efendi Vakfı ve Ayşe Hatun ibneti Sağir Mehmed Bey Vakfı'nın vakfiyesinde "eimme-i müçtehidin" yani müctehid imamlar tabiri ve "eimmetü'l-eşrâf" yani şerefli/değerli imamlar vasfı kullanılmıştır. ${ }^{63}$

Özetle vakfiyelerde İmâm-ı Ấzam hakkında onun, Hanefi mezhebinin önde gelen üç büyük imamından birisi olduğu, selef âlimleri arasında yer aldığı, hidayeti ve doğru yolu bulmada insanlara imamlık ve rehberlik ettiği, herkesin bu konuda kendisine uyduğu gibi hususlar ön plana çıkartılmıştır. Bunun yanı sıra İmâm-1 Âzam, kadim, civanmert, önde gelen, şerefli, değerli ve büyük bir İslâm âlimi olarak tavsif edilmiş, içtihat konusunda üstün bir makamda bulunduğu ve kendisinin ümmetin yolunu aydınlatan bir kandil olduğu hususu vurgulanmıştır. İsmi hayır, hürmet ve tazimle anılmış ve kendisine dualar edilmiştir. İmâm-1 Âzam ile ilgili bu tasavvurun Bektaşî tekkelerinde de olduğu tespit edilmiştir.

\section{Vakfiyelerde İmâm-1 Âzam'a ve Onun Görüşlerine Yer Verilmesinin Nedeni}

Osmanlı arşivinde bulunan birçok vakfiyede İmâm-1 Âzam ve onun fetvalarına yer verildiği görülmektedir. Bunun ana nedeni ise vakıftan rücû davası konusuyla ilgilidir. Rücû kelimesi aslen Arapça

\footnotetext{
57 VGMA, Defter 989/226/179.

58 VGMA, Defter 989/164/122; VGMA, Defter 989/165/123; VGMA, Defter 988/278/177.

59 VGMA, Defter 991/58/75.

60 VGMA, Defter 607/44/65; VGMA, Defter 988/142/56; VGMA, Defter 988/237/144; VGMA, Defter 989/180/137.

61 VGMA, Defter 633/21/11.

62 VGMA, Defter 990/156/154.

63 VGMA, Defter 988/286/184; VGMA, Defter 987/274/95; VGMA, Defter 989/185/141.
} 
H. TELLİ / Al-Imam al-A'zam Abu Hanifa and His Views in Ottoman Foundation Documents: Example of Macedonia Waqfiyyas I 467 olup geri "dönmek, vazgeçmek" anlamına gelmektedir. ${ }^{64}$ Vakıftan rücû davası ise vâkıfın vakfından geri dönmek, vazgeçmek ve vakfını iptal etmek amacıyla meclis-i şer'ide hâkimin/kadının bazen de vakfiye kâtibinin huzurunda vakfın mütevellisine karşı açtığı davaya denmektedir. Birçok vakfiyede vakıftan rücû davasının yer aldığ 1 görülmektedir. Bu davadan bahsedilen kısım genellikle vakfiyenin son bölümünde ve özet olarak bulunmaktadır. ${ }^{65}$

Rücû davasının içeriğinde vâkıfın vakfından geri dönme amacıyla getirdiği çeşitli delillerle ilgili bilgiler bulunmaktadır. Bu delillerin başında İmâm-ı Âzam'ın vakıfla ilgili görüşleri/içtihatları vardır. Bu yüzden rücû davalarının olduğu vakfiyelerde İmâm-1 Âzam'a ve onun içtihatlarına da yer verildiği görülür. Vâkıf, İmâm-ı Âzam'ın görüşlerine dayanarak ortaya koyduğu delillerle vakfının sahih olmadığını veya sahih olsa da lâzım yani hukuki olarak bağlayıcı olmadığını ispatlamaya çalışmıştır. Vâkıf, vakfının lâzım/bağlayıcı olmadığını ispatlamak suretiyle vakfından rücû etme hakkına sahip olduğunu ve bu hakkını da kullanarak vakfından rücû etmek istediğini ifade etmiştir. Vâkıfın bu delilleri karşısında vakfın mütevellisi ise genellikle İmâm-ı Âzam'ın görüşlerinin karşısında yer alan Ebû Yusuf ve İmâm Muhammed'in görüşlerini savunmuş, vakfın sahih ve lâzım olduğunu ifade etmiş ve vakıftan rücûun olamayacağını ispatlamaya ve delillendirmeye çalışmıştır. Her iki tarafın delillerini dinleyen ve hüküm verme yetkisine sahip olan hâkim veya kadı, konuyla ilgili son kararını vermiştir. Bu kararını da vakfiyenin sonunda ifade etmiştir. İncelenen vakfiyelerde bu kararın tamamının vakıftan rücû etme yönünde deliller sunan vâkıfın aleyhinde olduğu görülmüştür. Hâkim, vakfın sahih ve lâzım olduğuna ve vakıftan rücûun mümkün olamayacağına karar vermiş ve bu kararını vakfiyenin sonuna eklemiştir. ${ }^{66} \mathrm{Bu}$ arada zihinlere vâkıfın, vakıf eseri/eserleri inşa etmişken, menkul ve gayrimenkulünü bu vakfı için tahsis etmişken, çeşitli şartlarını vakfiyesine yazdırmışken yani vakıf

64 Mevlüt Sarı, El-Mevarid Arapça-Türkçe Lugat (İstanbul: Bahar Yayınları, 1984), 580.

65 VGMA, Defter 607/44/65; VGMA, Defter 988/142/56; VGMA, Defter 988/237/144; VGMA, Defter 991/45/57.

66 VGMA, Defter 988/286/184; VGMA, Defter 991/45/57; VGMA, Defter 989/226/179; VGMA, Defter 989/164/122; VGMA, Defter 989/165/123; VGMA, Defter 988/278/177; VGMA, Defter 991/58/75; VGMA, Defter 607/44/65; VGMA, Defter 988/142/56; VGMA, Defter 988/237/144; VGMA, Defter 989/180/137; VGMA, Defter 633/21/11. 
468 | H. TELLİ / Osmanlı Vakıf Belgelerinde İmâm-1 Âzam Ebû Hanîfe ve Görüşleri: Makedonya Vakfiyeleri Örneği

için tüm hazırlıkları yapmış ve vakfını daha yeni kurmuşken vakfını iptal etmek amacıyla neden rücû davası açtığı konusu gelmektedir.

Rücû davaları incelendiğinde aslında bu tür davaların, vâkıf tarafından sonucu aleyhine olacak şekilde bile bile açılan, fikri planda farazi bir murafaa (yargılama)/mizansen ve kurgusal, ancak hukuki açıdan bağlayıcı olan davalar olduğu anlaşılmıştır. Aslında vâkıf, daha sonradan gerek kendisi gerekse mirasçıları tarafından rücû davasının açılmasını önlemek ve bu dava konusunu bir daha gündeme getirmemek amacıyla vakfını kurduğu daha ilk andan itibaren vakfiyesini yazdırdığı meclis-i şer'îde rücû davası açmış, davayı kaybetmiş, vakfın sahih ve lâzım olduğunu ve rücûun bir daha mümkün olamayacağını içeren hâkimin kararını vakfiyesine yazdırmıştır. Böylece vâkıf vakfını daha da sağlamlaştırmış ve ebedî kılmıştır. Vâkıf böylece sonradan vakıf yaptığı için pişman olup da vakfından geri dönmek isterse böyle bir yolu kendisine ilk başta kapatmıştır. Kendisinden sonra mirasçıları dâhil olmak üzere hiçbir kimsenin vakfını iptal etmek için herhangi bir teşebbüste bulunmasını daha ilk andan itibaren engellemiştir. ${ }^{67}$

\section{Vakfiyelerde İmâm-1 Âzam'ın Görüşleri ve Fetvaları}

\subsection{Vakfın Tanımı İle İlgili Görüşü}

İmâm-ı Âzam'a göre vakıf, mülk olan bir malı başkasına temlikten hapsetmek/alıkoymak demektir.68 İmâm-1 Âzam, "وقف" (vakf) kelimesini özellikle "حبس/ (habs: alıkoymak/tutmak) manasında kullanmış ve değerlendirmiştir. Konuyla ilgili vakfiyelere bakıldığında vâkıfların vakf kelimesini İmâm-1 Âzam'ın tanımlamasına uygun olarak habs manasında kullanmaya özen gösterdikleri tespit edilmiştir. Örneğin Köprülü'de ashâb-1 hayrâttan Şaban Ağa, sahip olduğu bir bab (bölüm) fırını vakfederken vakıf kelimesini İmâm-1 Âzam'ın görüşüne uygun olarak habs manasında kullandığını 27 Zilkade 1324/12 Ocak 1907 tarihli vakfiyesinde şöyle ifade etmiştir. "Bir bāb fırūnımı hasbeten lillahi'l'az̄īm ve țaleben li-merżātillāhi'l-kerīm vakf-1 șahīh-i müebbed ve habs-i șarīh-i muhalled vaḳf ve habs edüb." ${ }^{69}$ Şaban Ağa habs kelimesini "ebedî

67 Telli, “Osmanlı Döneminde Üsküp Vakfiyelerinde Görülen Vakıftan Rücû’ Davaları ve Fıkhi Meseleler", Uluslararası Sosyal Araştırmalar Dergisi 11/55 (2018), 1043-1058.

68 Ebû Bekr Şemsü'l-eimme es-Serahsî, Kitâbu'l-Mebsût (Beyrut: Dâru'l-Ma'rife, ts.), $12 / 27$.

69 VGMA, Defter 990/91/77. 
H. TELLİ / Al-Imam al-A'zam Abu Hanifa and His Views in Ottoman Foundation Documents: Example of Macedonia Waqfiyyas | 469 ve açık bir alıkoymayla vakfettim" manasındaki "ḥabs-i șarīhn-i muhalled" terkibiyle kullanmıştır. Vakıf manasındaki habs kelimesi bazı vakfiyelerde farklı terkiplerle de kullanılmıştır. Örneğin Kratova'da Ahmed Naib Efendi bin Mustafa, 1 Rebiü'l-evvel 1277/17 Eylül 1860 tarihli vakfiyesinde habs kelimesini "habs-i șarīh-i meri'yyi" terkibiyle kullanmış ve mevkûfunu hükmü geçen makbul ve açık bir alıkoymayla vakfettiğini beyan etmiştir. ${ }^{70}$

Makedonya vakfiyelerinin hemen hemen hepsinde "vakf" kelimesinin İmâm-1 Âzam'ın görüşüne uygun olarak "habs" manasında kullanıldığı tespit edilmiştir. ${ }^{71}$

\subsection{Vakfın Sıhhati ve Lüzûmu İle İlgili Görüşü}

Vakfın sıhhati, vakfın sahih olması anlamına gelir. Eğer vakfeden bir kişi başkasının değil de kendi şahsi malından vakıfta bulunuyorsa buna sahih vakıf denilmektedir. Böyle bir durumda vakfedilen malın/arazinin mülkiyeti vâkıfın elinden çıkar ve vakfa devredilmiş olur. Böylece vakfın sıhhati gerçekleşmiş olur. Vakfın lüzûmu ise vakfın hukuki olarak bağlayıcı hale gelmesi demektir. Eğer vakıf, lâzım yani hukuken bağlayıcı olursa bu durumda bu vakfın feshi mümkün olmamaktadır. Osmanlı tatbikatında vakfın sıhhati ve lüzûmu denince bu bilgiler akla gelir.72 Ancak İmâm-1 Âzam vakfın sıhhati ve lüzûmu konusunda daha farklı bir yaklaşım sergilemektedir. ${ }^{73}$ Bu hususta İmâm1 Âzam "Hâkim karar vermedikçe veya vakfeden, vakfı kendi ölümüne bağlamadıkça onun vakıf malı üzerindeki mülkiyet hakkı ortadan

70 VGMA, Defter 990/77/65.

71 VGMA, Defter 990/91/77; VGMA, Defter 597/81/47; VGMA, Defter 600/262/328; VGMA, Defter 605/137/194; VGMA, Defter 604/146/197; VGMA, Defter 582-2/373/280; VGMA, Defter 989/167/126; VGMA, Defter 604/145/196; VGMA, Defter 989/122/86; VGMA, Defter 989/174/132; VGMA, Defter 991/24/26; VGMA, Defter 989/244/190; VGMA, Defter 609/253/305; VGMA, Defter 601/157/204.

72 Telli, Osmanlı Dönemi Üsküp Vakıfları, 19, 21.

73 İmâm-1 Âzâm'ın (Numan b. Sabit'in) vakıf tesciliyle ilgili görüşleri için bk. Ömer Hilmi Efendi (Karînabâdîzâde) (ö. 1307/1889), İthâfü'l-Ahlâf Fî̀ Ahkâmi'l-Evkâf, (İstanbul: Matbayı Amire, 1307), m. 4; Eminefendizâde Küçük Ali Haydar Efendi (ö. 1935), Tertîbu's-Sünûf fî Ahkâmi'l-Vukûf, (Dersaadet: 1339-1340/1920-1921), md. 3-4; Yasin Yılmaz, Örfîzâde Vakfı, (Ankara: Semih Ofset, 2012), 53. 
470 | H. TELLİ / Osmanlı Vakıf Belgelerinde İmâm-1 Âzam Ebû Hanîfe ve Görüşleri: Makedonya Vakfiyeleri Örneği

kalkmaz" demektedir. ${ }^{74}$ Yani İmâm-1 Âzam'a göre vakıf sahih olsa da hâkim karar vermedikçe lâzım (hukuken geçerli) olmamıştır. Eğer bir vakıf, lâzım değilse o vakıftan dönmek de meşrû ve câizdir. İmâm-1 Âzam'ın bu konudaki fetvası Makedonya vakfiyelerinde birkaç formda gündeme getirilmiştir. Bu formlar şunlardır:

- "İmām-1 A'ẓam radịyallahu 'anhu mežhebince lāẓım değil”75

- "Hażreti İmām-1 A'ẓam ve müctehid-i aḳdem 'indinde șahị̣̂ lākin gayri lāzıım olmağın"76

- “İmām-ı A'ẓam müşārun ileyh ḳatında sıḥhat lüzūmu müstelzim olmadığ ${ }^{\prime \prime}$

- "İmām Ebū Hanīfe naẓarında șıhḥat, müstelzim-i lüẓūm değildir"78

- "Kavl-i muhtār üzere șıḥhati lüzūmunu müstelzim olmadığından"79

Tüm bu formalarda ifade edilmek istenen mana şudur: İmâm-1 Âzam'ın fetvasına göre vakıf sahihtir ancak sahih olması lâzım (hukuken bağlayıcı) olmasını gerekli kılmaz.

Makedonya vakfiyelerinde farklı form ve ifadelerle dile getirilen İmâm-1 Âzam'ın bu konudaki fetvasını "vaḳıın sıhhati lüzûmunu müstelzim kılmaz" (yani vakfın sahih olması lâzım olmasını gerekli kılmaz) şeklinde tek bir cümlede özetlemek ve formüle etmek mümkündür. Bu fetva aynı zamanda vakfın geçerli olması için vâkıfın "Ben vakfettim" demesinin yeterli olmadığı ve vakıftan rücûun mümkün ve câiz olduğu manalarını da içermektedir.

Makedonya coğrafyasında farklı yüzyıllarda kurulan vakıflara ait vakfiyelerde vakfın sihhati ve lüzûmu konusunun nasıl ele alındığını birkaç örnekle incelemek istiyoruz.

16. yüzyılın başlarında Sultan II. Bayezid Han dönemi vezirlerinden olan ve Üsküp'ün en önemli vakıf kurucularından biri

74 Ebü'l-Hasen Burhânüddîn Alî b. Ebî Bekr b. Abdilcelîl el-Fergānî el-Mergīnānī, elHidāyetü şerḥu Bidāyeti'l-Mubtedī, thk. Muhammed Adnân Dervîş (Beyrut: Şeriketü Dâri'l-Erkâm, ts.), 3/5.

75 VGMA, Defter 629/423/333.

76 VGMA, Defter 630/1338/816.

77 VGMA, Defter 988/286/184.

78 VGMA, Defter 991/45/57.

79 VGMA, Defter 597/89/59. 
olan Gazi Yahya Paşa bin Abdulhay, Üsküp'te cami, imaret, hamam, muallimhane, tabhane, imarethane gibi birçok vakıf eserini inşa ettirmiş ve bu eserlerde hizmetlerin devam etmesi için Üsküp, Sofya, Filibe, Niğbolu, İstanbul vb. yerlerde 20 civarında değirmeni, 70' den fazla evi, 400'den fazla dükkânı, pek çok sayıda bağ, bahçe, arsa ve çeşmeyi vakfetmiştir. ${ }^{80}$ Yahya Paşa, Receb 912/Kasım 1506 tarihli vakfiyesinde meclis-i şer'ide müvekkili Usul Çelebi bin Yusuf vasıtasıyla vakfının sahih olduğunu ancak İmâm-1 Âzam katında bu sıhhatin lüzûmu gerekli kılmadığını ifade ederek vakfından rücû etmek istediğini belirtir. Vakfın mütevellisi: "İmām Ebī Yūsuf ḳavli üzere mücerred vakfettim demekle vaḳf lāẓım olūb rücū' șahịh olmaz ve tağyīri dahi kāail olmaz" diyerek bu durumu reddeder. Hâkim de Ebu Yusuf'un fetvasına göre amel ederek vakfın sahih ve lâzım olduğuna karar verir. Verdiği karardan sonra hiç kimsenin vakıfta, tebdil, tağyir ve iptal yetkisine sahip olamayacağını belirtir. Vakfı iptal ve tağyir edenlerin Cenab-1 Hak katında büyük bir vebali ve günahı yükleneceklerini, elim bir azaba duçar olacaklarını ve bu kimselerin dünyada zalimlerden sayılacağını söyler. Buna mukabil vakfın ibkâsı ve ihyası için çalışanların dünyada ihsan sahiplerinden sayılacağını, ahirette ecir ve mükâfata nail olacaklarını, hiçbir Müslümanın vakfın harabına ve yok olmasına sebep olamayacağını ve hilaf-1 şer'ide tasarrufta bulanamayacağını ifade eder. Hâkim bu ifadeleriyle vakfı yok ve iptal etmeye çalışanların karşısında olduğunu ve buna asla müsaade etmeyeceğini açıkça beyan eder. Böylece bu davada hâkim İmâm-1 Âzam'ın fetvasına göre değil Ebû Yûsuf ve İmâm Muhammed'in fetvalarına göre amel ettiğini açıkça göstermiş olur. ${ }^{81}$

18. yüzyılın başlarında Abdülbaki Efendi adlı bir hayır sahibi Üsküp'te bir eczâhane (cüz okunan yer) yaptırmış ve burası için dükkânlar, değirmenler ve bahçeler vakfetmiştir. Abdülbaki Efendi'nin 20 Zilkade 1128/5 Kasım 1716 tarihli vakfiyesinin son kısmında vakfın sıhhati ve lüzûmu konusuna yer verilmiştir. Abdülbaki Efendi, vakfını tescil ettirmek için geldiği meclis-i şer'ide; "İmām-1 A'ẓam ve hümām-1 efham re'y-i şerīflerinde sıḥhat lüzūmu müstelzim olmamağla arsa-i mevḳūfe-i mezbūre üzerinde olan ebniyye-i mezkūranın vakfiyyetinden

80 Telli, Osmanl Dönemi Üsküp Vakıfları, 119-121.

81 VGMA, Defter 629/423/333. 
472 | H. TELLİ / Osmanlı Vakıf Belgelerinde İmâm-1 Âzam Ebû Hanîfe ve Görüşleri: Makedonya Vakfiyeleri Örneği

tekrar rucū' eyledim." 82 diyerek vakfından rücû etmek/geri dönmek istediğini ifade eder. Ancak vakfın mütevellisi;

“İmām-ı Aẓam müşārun ileyh ḳatında sıḥhat lüzūmu müstelzim olmadı̆̆ı muḳarrara

lakin İmām Ebū Yūsuf Hażretleri mezhheb-i şerīflerinde vāḳıf mücerred vaḳaftu demekle

ve İmâm Muhammed Ḥażretleri ḳatında teslīm ile'l-mütevellī ve zikr-i te'bid ile vaḳf

lāzım olmağla" 83

diyerek İmâm-1 Âzam'ın bu fetvasının uygulanamayacağını dile getirir. Bu konuda Ebû Yûsuf'a göre "vakffettim" dedikten sonra ve İmâm Muhammed'e göre vakfedilen mal mütevelliye teslim edildikten ve "ebedî olarak vakfettim" ifadesi kullanıldıktan sonra vakfın hukuken geçerli olacağını beyan ederek vakfın lüzûmuna hükmedilmesini talep eder. Kadı da vakfın devamını daha evla görerek vakfın sahih ve lâzım olduğuna karar verir. Böylece vakfiyede dile getirilen İmâm-1 Âzam'ın fetvası ile değil Ebû Yûsuf ve İmâm Muhammed'in fetvalarına göre karar verilir ve bu şekilde amel edilir. ${ }^{84}$

19. yüzyılın sonlarında Kratova'dan Emine Hanım binti Hacı Ali Bey, Dimonçe köyünde sahip olduğu değirmenini Allah için vakfeder ve bu değirmenden elde edilen geliri Kratova'daki Sultan Murad Camii'nde hitâbet ve müezzinlik cihetini yürüten zatların maaşı için tahsis eder. 7 Şaban 1316/21 Aralık 1898 tarihli vakfiyesinde Emine Hanim:

“vaḳf-1 'aḳār İmām-1 A'ẓam ve hümām-1 efham Ebū Hanīfeti'l-Kūfī Hażretleri ind-i

'ālīlerinde șahịḥ olūb lākin ḳavl-i muhtār üzere sıḥhati lüzūmunu müstelzim olmadığından vaḳf ġayr-i lāzım menzile-i 'āriyette olduğuna naẓāran vaḳf-ı mežkūrdan rucū' muvāfıḳ-1 şer'-i şerīf olmağla" 85

diyerek vakf-1 akârının İmâm-ı Âzam nazarında sahih olduğunu ancak kavl-i muhtara göre bu sıhhatin lüzûmunu gerekli kılmadığını, bundan dolayı da vakfının lâzım yani hukuken geçerli olmadığını ve vakfından geri dönmesinin şer-i şerife uygun olduğunu ifade eder ve vakfından rücû etmek istediğini beyan eder. Vakfın mütevellisi bu konuda İmâm Ebû Yûsuf'un mücerred olarak vakfettim denildikten sonra vakfın sahih olduğunu ve İmâm Muhammed'in mevkufun mütevelliye teslim edildikten sonra vakfın lâzım olduğunu ifade eden

82 VGMA, Defter 988/286/184.

83 VGMA, Defter 988/286/184.

84 VGMA, Defter 988/286/184.

85 VGM, Defter 597/89/59. 
H. TELLİ / Al-Imam al-A'zam Abu Hanifa and His Views in Ottoman Foundation Documents: Example of Macedonia Waqfiyyas I 473

fetvalarını delil göstererek itiraz eder. Tarafların delillerini dinleyen hâkim, hayrı iptal etmekten çekinerek ve selef âlimleri arasında câri (genel geçerli) olan hükme ittiba ederek vakfın sahih ve lâzım olduğuna karar verir. Böylece hâkim, İmâm-1 Âzam'ın fetvasına göre değil Ebû Yûsuf ve İmâm Muhammed'in görüşlerine göre amel eder. ${ }^{86}$

20. yüzyılın başlarında Ứsküp'ün Barova köyü ahalisinden olan Nureddin bin Osman bin Yusuf, sahip olduğu 13 Osmanî altını vakfederek bir vakıf kurar. Vâkıf, 22 Şevvâl 1329/16 Ekim 1911 tarihli vakfiyesinde "İmām Ebū Ḥanīfe naẓarında sıḥhat, müstelzim-i lüzūm değildir" diyerek vakfından rücû etmek ister. Nuredddin'in meclis-i şer'ideki bu ifadesine karşı vakfın mütevelli "Ebū Yūsuf'a ve İmām Muḥammed'e göre sıḥhat lüzūmden ġayr-i mufārıḳtır" diyerek karşı çıkar. Yani vakfın sıhhati ve lüzûmu ayrı ayrı düşünülemez, bu ikisi birbirinden ayrı tutulamaz, vakıf sahih olduğunda aynı anda lâzım da olur diyerek rücûa engel olmaya çalışır. Tarafları dinleyen kadı, "mütevelli-i merḳūmūn taḳ̂îr-i meşrūḥu vāḳı'a muțābık ve nefsü'l-emre muvāfıḳtır" diyerek mütevellinin lehinde karar verir ve vakfın sahih ve lâzım olduğuna hükmeder. Böylece kadı, bu kararıyla İmâm-1 Âzam'a göre değil Ebû Yusûf ve İmâm Muhammed'in görüşlerine göre amel eder. ${ }^{87}$

Üsküp'te Murat Paşa Camii, İbni Muhtesib Camii ve Murana Köyü Camii'nin ihtiyaçları ve görevlilerinin maaşlarının karşılanması için sahip olduğu 3 dükkânını ve 2 bab odasını vakfeden Şafizade Seyyid Sadi Efendi'nin Rebiü'l-evvel 1131/Ocak 1719 tarihli vakfiyesi, 88 yine Üsküp'ün Rifâî Tarikatı şeyhlerinden olup Üsküp'te Hatuncuklar Mahallesi'nde bir tekke bina ederek bir vakıf kuran Şeyh Mehmed Efendi'nin 13 Cemâziye'l-ahir 1233/20 Nisan 1818 tarihli vakfiyesi ${ }^{89}$ ve Gostivar'da Halvetî tarikatı şeyhlerinden Şeyh Nuh Efendi Vakfı'nın 11 Zilkade 1219/11 Şubat 1805 tarihli vakfiyesi ${ }^{90}$ gibi birçok vakfiyede İmâm-1 Âzam'a dayandırılan ve "vakfın sıhhati lüzûmunu müstelzim kılmaz" şeklinde formüle edilen fetvası sık sık gündeme getirilmiştir. Vâkıflar, İmâm-1 Âzam'ın bu görüşünü delil getirerek vakıftan rücû

\footnotetext{
86 VGMA, Defter 597/89/59.

87 VGMA, Defter 991/45/57.

88 VGMA, Defter 989/185/141.

89 VGMA, Defter 631/25/10.

90 VGMA, Defter 629/736/489.
} 
474 | H. TELLİ / Osmanlı Vakıf Belgelerinde İmâm-1 Âzam Ebû Hanîfe ve Görüşleri: Makedonya Vakfiyeleri Örneği

etmek istemişlerdir. Mütevelliler ise Ebû Yûsuf ve İmâm Muhammed'in fetvalarını delil göstererek buna itiraz etmişlerdir. Kadı ise fukahaya ihtilaf etmemek ve hayra engel olmamak gayesiyle vakfın sahih ve lâzım olduğuna karar vermiş ve kararını da vakfiyelere kaydetmiştir.

Vakfın sıhhati ve lüzumu konusundan bahseden tüm vakfiyeler incelendiğinde İmâm-1 Âzam'ın fetvasının uygulanmadığ görülmektedir. Aslında bu fetvanın uygulanmaması zahiri anlamdadır. Rücû davasında vâkıfın esas gayesi vakıftan dönmek değil vakfı sağlamlaştırmak ve ebedî kılmak olduğundan İmâm-1 Âzam'ın uygulanmıyor gibi görünen fetvalarının aslında vakfı sağlamlaştırma ve ebedî kılma adına bir aracı olarak gündeme getirildiği ve vakfiyelerde bu maksatlarla yer verildiği anlaşılmaktadır. Dolayısıyla Osmanlı vakıf tatbikatında İmâm-1 Âzam'ın vakfın sıhhati ve lüzumu konusundaki fetvasının, vakfın te'bidi (ebedîliği) ve teşyidi (sağlamlaştırılması) açısından çok önemli pozitif bir rol üstlendiği görülmektedir.

\subsection{Vakf-1 Akârla İlgili Görüşü}

Bina, arazi, bağ, bahçe, tarla, dükkân ve ev gibi nakli mümkün olmayan mala akar denir. ${ }^{91}$ Gayrimenkul olarak da adlandırılan akar, kira veya gelir getiren maldır. Vakf-ı akâr (akarât-ı mevkûfe) ise vakfa gelir getiren gayrimenkule denir. Cami, medrese, tekke, zaviye, imarethane gibi müessesât-1 hayriyye kabilinden vakıf eserlerinin tamir, genişletme, yeniden inşa etme gibi ihyası, vakıf hizmetlerinin ayakta kalması ve idamesi ve vakıf görevlilerinin maaşlarının karşılanması vakf-1 akârlar sayesinde gerçekleşir. ${ }^{92}$ Bu yönüyle vakf-1 akârlar vakıflar ve vakıf hizmetleri açısından oldukça önemlidir. Vakf-1 akârın mülkiyetinin kime ait olduğu ve vakfın lüzumu açısından ne gibi bir konumda bulunduğu konusunda âlimler arasında farklı görüşler ortaya atılmıştır. Osmanlı dönemi vakfiyelerine bakıldığında vakf-ı akârla ilgili İmâm-1 Âzam, Ebû Yûsuf ve İmâm Muhammed'in fetvalarına yer verildiği görülür.

İmâm-1 Âzam'a göre vakıf, bir malı ('aynı) vâkıfın mülkünde olmak kaydıyla menfaatini tasadduk etmek anlamina gelmektedir. Buna göre vakfeden kişi mevkûfu kendi mülkünde tutmakta, mevkûfun

91 Ali Şafak, "Akar”, Türkiye Diyanet Vakfi İslâm Ansiklopedisi (İstanbul: TDV Yayınları, 1989), 2/221.

92 Vakıflar Genel Müdürlüğü, “Vakıf Deyimleri ve Terimleri Sözlüğü”, (Erişim 03 Temmuz 2020). 
H. TELLİ / Al-Imam al-A'zam Abu Hanifa and His Views in Ottoman Foundation Documents: Example of Macedonia Waqfiyyas | 475 menfaatini ise başkasının kullanımına tahsis ve tasadduk etmektedir. Bir malın mülkünü değil de sadece menfaatini tasadduk etmek ise ödünç vermeye benzemektedir. Şurası da var ki menfaat ise ma'dumdur yani belirsizdir. Belirsiz bir şeyin tasadduku ise sahih değildir. Bu yüzden vakıf aslen caiz olmayan bir durumdur. Buna mukabil İmâm-1 Âzam vakfı caiz görür. Ancak vakfın ödünç vermeye benzediğini ve lâzım yani bağlayıcı olmadığını ifade eder. Bu durumda İmâm-ı Âzam'a göre vakıf bağlayıcı olmadığı için vakıftan dönmek câizdir. Ebû Yûsuf ve İmâm Muhammed'e göre ise vâkıf, vakfettiği malı kendi mülkünde değil Allah'ın mülkünde olmak kaydıyla o malın menfaatini tasadduk etmektedir. Böylece vâkıf, bir malı vakfettiği zaman o malı kendi mülkünden çıkarmış olur. Bu durumda vakıf da lâzım (bağlayıcı) olur ve vakıftan rücû etmek de caiz değildir. ${ }^{93}$

İmâm-1 Âzam'in vakf-1 akârın caiz olduğu ancak ödünç konumunda bulunduğu ve bu yüzden vakfın bağlayıcı olmadığı konusundaki görüşü birçok vakfiyede de gündeme getirilmiştir. Onun bu konudaki görüşü Makedonya vakfiyelerinde birçok formda ele alınmıştır. Bu formlar şunlardır;

- Vaḳf-1 'aḳār İmām-1 A'ẓam ve hümām-1 efham Ebū Hanīfeti'1-Kūfī Hażretleri indinde menzile-i āriyette olmağla rücūu meşrū'‘94

- "Vaḳf-1 'aḳār muhtāru'l-eimmeti ahbār olan İmām-1 A'ẓam ve hümām-1 aḳdem sirācü'l-ümmeti kāşifü'l-gammi hażretleri indinde șaḥịh lakin menzile-i āriyette olub şeref-i lüzūmu müstelzim olmamağla vaḳf-1 mezbūrdan rucū' caiz" ${ }^{\prime 95}$

- “Vaḳf-1 'aḳār İmām-1 A'ẓam ve hümām-1 efham sirācü'1-milleti ve'd-dīn Ebū Hanīfeti'l-Kūfī Hażretleri indinde ṣaḥị̣ ise de lakin menzile-i āriyette olub sıḥhat lüzūmu müstelzim olmamağla benim içūn şer'an bāb-1 rücū'u meftūhoưr' 96

Vakf-1 akâr konusundaki tüm bu formlarda ifade edilmek istenen mana özetle şudur: İmâm-1 Âzam'a göre vakf-1 akâr ödünç

93 Mergīnānī, el-Hidāye, 3/15; Esad Muhammed Said es-Sâğircî, Delilleriyle Hanefi Fıkhı, çev. Halil Aldemir vd. (İstanbul: KarıncaEPolen Yayınları, 2009), 995; Celal Yeniçeri, "Ebû Hanîfe'nin Hayatı, Malî ve İktisadî Görüşleri”, Marmara Üniversitesi İlahiyat Fakültesi Dergisi 4 (1986), 270.

94 VGMA, Defter 989/234/185; VGMA, Defter 991/58/75.

95 VGMA, Defter 583/146/129.

96 VGMA, Defter 988/237/144. 
476 | H. TELLİ / Osmanlı Vakıf Belgelerinde İmâm-1 Âzam Ebû Hanîfe ve Görüşleri: Makedonya Vakfiyeleri Örneği

hükmündedir. Bundan dolayı vakıf, lâzım değildir. Yani hukuken bağlayıcı değildir. Bu yüzden de vakıftan rücû etmek caizdir.

Makedonya vakfiyelerinde farklı formlarda ifade edilen İmâm-1 Âzam'ın bu konudaki fetvasını "Vaḳf-ı 'aḳār İmām-ı A ẓam indinde menzile-i āriyette olmağla rücūu meşrū'dur" (yani İmâm-1 Âzam'a göre ödünç konumunda olduğundan vakf-1 akârdan dönmek caizdir) şeklinde tek bir cümlede özetlemek ve formüle etmek mümkündür.

Makedonya'da kurulan vakıflara ait vakfiyelerde vakf-ı akâr konusunun nasıl ele alındığını birkaç örnekle incelemek istiyoruz.

18. yüzyılın ortalarında Doyran'da Hatice Hatun binti Hacı Ahmed bir vakıf kurar. Hatice Hatun, Doyran'ın yakınında Derebaş mevkiinde sahip olduğu arsasını, bahçesini ve bir bab değirmenini Allah için vakfeder. 28 Muharrem 1174/9 Eylül 1760 tarihli vakfiyesinde mevkûfun kirasından elde edilen gelirin Doyran'da Mesih Bey mahallesinde bulunan Şeyh Yahya Efendi'nin bina eylediği Hangah'ın şeyhi Mehmed Efendi'ye meşrûta olmasını, değirmenin mezkûr şeyh tarafindan idare olunmasını, ramazan aylarında Mesih Bey Mahallesi Mescidi'ndeki cemaate iftar verilmesini şart koşar. Hatice Hatun;

\footnotetext{
“Vaḳf-1 'aḳār İmām-1 Aẓam efham Ḥażretleri katında gayr-i șahịh olduğuna binaen müvekkilem mezbūra țaraf-1 vifāḳdan semt-i şiḳāḳa șarf-1 inān edüb akạār-1 mezbūrun vakfiyetinden rücū' vekālen ve led-i mülkiyete idḩāl murād etmekle reddiyle bi'l-vekāle hükm țaleb ederim." $" 97$
}

diyerek vakf-ı akârının İmâm-ı Âzam katında gayr-i sahih olduğunu ve vakfından rücû etmek istediğini beyan eder. Vakfın mütevellisi ise İmâm-ı Âzam katında durumun öyle olduğunu ancak İmâm Ebû Yûsuf ve İmâm Muhammed'in içtihatlarına göre vâkıf "vakfettim" demesiyle ve mevkûfu mütevelliye teslim etmesiyle vakfın sahih ve lâzım olduğunu beyan eder. Hâkim Efendi, vakfın ezeli ve uhrevi olduğuna itibar ederek ve en faydalı olan kavli esas alarak Ebû Yûsuf ve İmâm Muhammed'in fetvalarına göre amel eder ve vakfın sahih ve lâzım olduğuna karar verir. ${ }^{98}$

19. yüzyılın ortalarında Manastır' da bir Rifâî dergâhı yaptıran ve bu dergâh için birçok akarını vakfeden Seyyid Mehmed Nazmi Efendi, 9 Şevval 1278/9 Nisan 1862 tarihli vakfiyesinde;

97 VGMA, Defter 609/253/305.

98 VGMA, Defter 609/253/305. 
H. TELLİ / Al-Imam al-A'zam Abu Hanifa and His Views in Ottoman Foundation Documents: Example of Macedonia Waqfiyyas | 477

"vaḳf-1 'aḳār muhtāru'l-eimmeti ahbār olan İmām-1 A‘ẓam ve hümām-1 aḳdem sirācü'lümmeti kāşifü'l-gammi hażretleri indinde șahīḥ lakin menzile-i āriyette olub şeref-i lüzūmu müstelzim olmamağla vaḳf-ı mezbūrdan rucū' cāiz ve rāciìyy-i meşrūiyyi ğayri mütecāviz olmağın kel-evveli mülküme istirdād ederim. " 99

diyerek vakf-1 akârının İmâm-1 Âzam nazarında sahih ancak ödünç konumunda olduğunu, bu yüzden vakfının hukuken geçerli olmasının gerekli görülemeyeceğini, vakfından geri dönmesinin câiz ve meşrû olduğunu ve bu şekilde geri dönmenin de vakfı zarara uğratmak anlamına gelmediğini ifade ederek vakfından rücû etmek ve daha önceki gibi vakfettiği malını tekrar kendi mülküne katmak istediğini ifade eder. Vakfın mütevellisi vâkıfın bu sözlerine ve talebine münasip bir üslupla şöyle cevap verir;

“ eğerçi inde'l- İmām-ı Aẓam hāāl basṭ ve tafșīl olunan minval üzere idūğü cā-yı eşkâl değildir. Lakin ārif-i șamedānī Ebū Yūsuf eş-şehīr bi'l-imām-i'śs-s̄ānī ḥażretleri indinde vāḳıf mücerred "vaḳaftü" demekle ve İmām-1 Rabbān̄̄ Muhammed bin Hasen eşŞeybānī indinde teslīm-i ile'l-mütevellī ve te'bīd zikriyle vakf lāzım olur."100

Yani vakfın mütevellisi, “İmâm-1 Âzam nazarında vakıfla ilgili durum geniş tutulsa da ve açıklanan hususlar üzere olsa da durum böyle dişardan göründüğü gibi değildir. Zira Ebû Yusuf'a göre vakfeden bir kişi "vakfettim" sözünü kullandıktan sonra ve İmâm Muhammed'e göre mevkûf mütevelliye teslim edildikten ve ebedîlik sözü söylendikten sonra vakıf hukuken geçerli olur." diyerek mevkûfu vâkıfa teslim etmekten kaçınır ve bu şekilde davada vakfın savunuculuğunu yapar. Tarafların bu sözlerini ve delillerini dinleyen kadı efendi, âlimler arasındaki ihtilafı bilerek ve bu konuda gerekeni yaparak vakfın sahih ve lâzım olduğuna hükmeder. Böylece bu davada İmâm-1 Âzam'ın fetvasına göre amel edilmediği görülür. ${ }^{101}$

20. yüzyılın başlarında Üsküp'te sahip olduğu evini vakfeden ve gelirini Üsküp'teki Faik Paşa Camii'nin müezzinin maaşı için tahsis eden Ayşe Hanım binti Mehmed Efendi, 17 Zilkade 1320/15 Şubat 1903 tarihli vakfiyesinde şöyle der;

\footnotetext{
99 VGMA, Defter 583/146/129.

100 VGMA, Defter 583/146/129.

101 VGMA, Defter 583/146/129.
} 
478 | H. TELLİ / Osmanlı Vakıf Belgelerinde İmâm-1 Âzam Ebû Hanîfe ve Görüşleri: Makedonya Vakfiyeleri Örneği

“Vaḳf-1 a'kar İmām-1 Aẓam ve hümām-1 efham Ebū Hanīfeti'1-Kūfī Hażretleri indinde menzile-i āriyette olmağla rücūu meşrū'... olduğuna bināen vaḳf-1 mezbūrdan rücū' ve menzil-i mahdūd-ı meẓkūr ke'l-evvel mülküme istirdād ederim." ${ }^{102}$

Ayşe Hanım, bu sözleriyle İmâm-1 Âzam'a göre vakf-1 akârının ödünç konumunda bulunduğunu ve bu yüzden vakfından rücû etme hakkına sahip olduğunu ifade ederek vakfından dönmek istediğini belirtir. Mütevellisi ise vakfın Ebû Yûsuf'un görüşüne göre sahih ve bağlayıcı olduğunu ve bu sebeple vakıftan geri dönmenin mümkün olmadığını ifade eder. Tarafların delillerini dinleyen Kadı, "mubț1l-1 hayr olmakdan hazerer ederek" yani hayrı ortadan kaldırmaktan endişe ederek ve bu konuda selefin genel câri hükmüne uyarak vakfın sıhhat ve lüzûmuna hükmeder. Böylece bu kararda İmâm-1 Âzam'ın değil Ebû Yûsuf ve İmâm Muhammed'in fetvalarının uygulandığı görülür. ${ }^{103}$

19. ve 20. yüzyılda Makedonya'nın çeşitli şehirlerinde kurulan birçok vakfın vakfiyesinde vakf-ı akârla ilgili konu benzer şekilde ele alınmıştır. Bu vakfiyeleri şöyle sıralayabiliriz;

- Koçana'da Hasan Bey Vakfı: Koçana'da yeni bir medrese yaptıran Hasan Bey, mezkûr şehirde sahip olduğu 26 dükkânını ve evini bu medrese için vakfeder. (Vakfiyenin tarihi: 11 Rebiü'l-evvel 1235/28 Aralık 1819). ${ }^{104}$

- Üsküp'te Mehmed Ali Bey bin Hasan Bey Vakfı: Vâkıf, Hacı Kasım Mahallesi'nde babası tarafından yaptırılan Hacı Hasan Medresesi için sahip olduğu bir bab kovacı dükkânını, Dervişan Mahallesi'ndeki evini ve Güreler köyündeki hanını vakfeder. (Vakfiyenin tarihi: 15 Ramazan 1254 /2 Aralık 1838). ${ }^{105}$

- İştip'te Veliyuddin Bey bin Ahmed Vakfı: Vâkıf, İştip'in Sinan Bey Mahallesi'nde Hotuna (Otinya) nehri kenarında bir arsasını vakfeder ve Nakşibendiye tarikatı halifelerinden Baba Yusuf adlı zât-1 muhteremin medfun olduğu bu arsada bir tekke inşa eder. (Vakfiyenin tarihi: 5 Receb 1291/18 Ağustos 1874). ${ }^{106}$

- Üsküp'te Mehmed Faik Paşa Vakfı: Üsküp'ün Hamidiyye Mahallesi'nde müceddeden bir câmi-i şerif yaptıran Mehmet Faik Paşa,

\footnotetext{
102 VGMA, Defter 989/234/185.

103 VGMA, Defter 989/234/185.

104 VGMA, Defter 989/170-127.

105 VGMA, Defter 988/142/56.

106 VGMA, Defter 988/259/162.
} 
H. TELLİ / Al-Imam al-A'zam Abu Hanifa and His Views in Ottoman Foundation Documents: Example of Macedonia Waqfiyyas I 479

bu cami için dört bâb dükkânını vakfeder. (Vakfiyenin tarihi: 11 Şevval 1301/miladi 4 Ağustos 1884). ${ }^{107}$

- Manastır'da Mehmed Faik Paşa Vakfı: Manastır'da bir cami yaptıran vâkıf, bu cami için sahip olduğu arsasını, bağını, dükkânını ve üç odalı, iki sofalı, avlulu ve bahçeli bir bab evini vakfeder. Mevkûftan elde edilen gelirin Faik Paşa Camii'nin imâmet ve hitâbet cihetleri ile caminin çeşitli masrafları için harcanmasını meşrûta kılar. (Vakfiyenin tarihi: 15 Rebiü'l-ahir 1310/5 Kasim 1892). ${ }^{108}$

- Üsküp'te Ramiz Bey bin Hasan Bey Vakfı: Hüdaverdi Mahallesi sakinlerinden Ramiz Bey, Üsküp'te Meddah Baba Camii avlusu ve arsası içinde bir bab dükkân yaptırır ve bunu mezkûr cami adina vakfeder. (Vakfiyenin tarihi: 13 Safer 1317/23 Haziran 1899). ${ }^{109}$

- Üsküp'te Atiyye Hanım binti Arslan Vakfı: Debbağ Şahin Mahallesi Mescidi'nin avlusunda beş odalı bir medrese yaptıran vâkıf bu medrese için bir fırın dükkânı vakfeder. (Vakfiyenin tarihi: 3 Zilhicce 1324/ 18 Ocak 1907). ${ }^{110}$

- Üsküp'te Arife Hatun binti Abdulkadri Efendi Vakfı: Cami-i Atik Mahallesi'nde oturan Arife Hatun, sahip olduğu bir bab evini vakfeder ve bu evinin kirasından elde edilecek gelirin Üsküp'teki Sultan Murad Camii'nin imamına maaş olarak verilmesini şart koşar. (Vakfiyenin tarihi: 18 Zilhicce 1326/11 Ocak 1909). ${ }^{111}$

- Üsküp'te Belkıs Hanım binti Mahmud Pertev Paşa Vakfı: Üsküp'te harabe haldeki Elaldı Sultan Tekkesi için yeni bir bina yaptıran Belkıs Hanım, bunu tekkeye vakfeder. (Vakfiyenin tarihi: 22 Muharrem 1328/3 Şubat 1910). ${ }^{112}$

- Üsküp'te Hacı Ahmed Ağa bin Hacı Hasan Ağa Vakfı: Üsküp'ün Haraççı Salahaddin Mahallesi'nde bir mescit yaptıran Hacı Ahmed Ağa, bu mescit için üç bab dükkânını ve evini vakfeder. (Vakfiyenin tarihi: 22 Rebiü'l-evvel 1328/3 Nisan 1910). ${ }^{113}$

\footnotetext{
107 VGMA, Defter 988/237/144.

108 VGMA, Defter 989/63/51.

109 VGMA, Defter 991/58/75.

110 VGMA, Defter 991/59/76.

111 VGMA, Defter 990/53/47.

112 VGMA, Defter 990/74/62.

113 VGMA, Defter 607/44/65.
} 
480 | H. TELLİ / Osmanlı Vakıf Belgelerinde İmâm-1 Âzam Ebû Hanîfe ve Görüşleri: Makedonya Vakfiyeleri Örneği

- İştip'te Timur Ağa Vakfı: İştip'in Beşirli köyünden Timur Ağa, sahip olduğu bağını vakfeder ve bağdan elde edilen gelirini köydeki camide hatip olan kişinin maaşı için meşrûta kılar. (Vakfiyenin tarihi: 4 Rebüiü'l-evvel 1330/22 Şubat 1912). ${ }^{114}$

- Üsküp'te Hafız Sabri Efendi Vakfı: Hafız Sabri, Üsküp'teki Köse Kadılar Cami-i Şerifi için bir bab dükkânı vakfeder. (Vakfiyenin tarihi: 2 Rebiü'lâhir 1320/9 Temmuz 1902). ${ }^{115}$

- Üsküp'te Hüseyin Bey bin Süleyman ve kardeşleri Vakfı: Üsküp'te sahip oldukları bir bab dükkânı vakfeder. (Vakfiyenin tarihi: 28 Safer 1319/16 Haziran 1909). ${ }^{116}$

- Manastır'da Besim Paşa bin Osman Bey Vakfı: Topçu alayı erkânından mirliva Besim Paşa, Manastır'da bir cami yaptırır ve sahip olduğu üç bab dükkânını bu caminin imâmet ve hitâbet cihetleri ile caminin tamir ve minaresinin kandil masrafları için harcanmasını şart koşar. (Vakfiyenin tarihi: 9 Rebiü'l-ahir 1264/15 Mart 1848). ${ }^{117}$

- Doyran'da İbrahim Ağa bin Temur Ağa ve Bekir Efendi bin Salih Vakfı: Robova köyünden olan bu iki vâkıftan biri 200 kuruş diğeri de 300 kuruş vakfederek müştereken bir vakıf kurarlar. Mevkuf 500 kuruşun istirbâh yoluyla elde edilen gelirini köydeki caminin imam ve hatip vazifelerini yürüten görevlilerin maaşı için tahsis ederler. (Vakfiyenin tarihi: 3 Cemâziye'l-evvel 1322/16 Temmuz 1904). ${ }^{118}$

- Debre'de Abdal bin Basri Vakfı: Rabdişt köyünden Abdal bin Basri sahip olduğu 3000 kuruş kıymetindeki bir bab dükkânını Allah için vakfeder. Dükkânın kirasından elde edilecek gelirin köydeki caminin imam ve hatibin maaşı ve dükkânın tamir ihtiyaçları için harcanmasını şart koşar. (Vakfiyenin tarihi: 17 Rebiü'l-ahir 1330/5 Nisan 1912). ${ }^{119}$

Vakf-1 akâr konusundan bahseden tüm vakfiyeler incelendiğinde İmâm-1 Âzam'ın değil Ebû Yûsuf ve İmâm Muhammed'in fetvasının uygulandığ1 ve durumun 18., 19. ve 20 yüzyılda aynı şekil ve formatta devam ettiği tespit edilmiştir. Aslında İmâm-1 Âzam'ın fetvasının

\footnotetext{
114 VGMA, Defter 604/138/183

115 VGMA, Defter 989/180/137.

116 VGMA, Defter 990/48/39.

117 VGMA, Defter 987/199/63.

118 VGMA, Defter 989/244/190.

119 VGMA, Defter 604/146/197.
} 
H. TELLİ / Al-Imam al-A'zam Abu Hanifa and His Views in Ottoman Foundation Documents: Example of Macedonia Waqfiyyas | 481 uygulanmaması yine zahiri anlamdadır. İmâm-1 Âzam'ın vakf-ı akârla ilgili fetvasının vâkıf tarafından bir aracı olarak kullanıldığı ve vâkıfın bundaki esas amacının vakfını ebedî kılmak ve sağlamlaştırmak olduğu tespit edilmiştir. Dolayısıyla İmâm-ı Âzam'ın bu konudaki fetvasının vakfın te'bidi (ebedîliği) ve teşyidi (sağlamlaştırılması) açısından Osmanlı vakıf tatbikatında çok önemli bir rol üstlendiği tespit edilmiştir.

\subsection{Vakf-1 Menkul İle İlgili Görüşü}

İmâm-1 Âzam menkulün yani taşınabilen ve değiştirilebilen malın vakfını mutlak manada câiz görmez. Ebû Yûsuf taşınmaz malın içindeki hayvanların ve köle çobanların vakfedilmesine, İmâm Muhammed ise at ve silah gibi menkulün vakfedilmesine cevaz verir. ${ }^{120}$ İmâm-1 Âzam'ın menkulün vakfının caiz olmadığı konusundaki fetvası vakfiyelerde de dile getirilmiştir.

Üsküp'ün Kavundere köyü ahalisinden Abdullah bin Hüseyin, köyde sahip olduğu dört dönüm bağını ve bu bağdaki ağaçları köydeki camii için vakfeder ve mevkûfunu mütevelliye teslim eder. Üsküp Hükümet Konağı'nda mahkeme-i şer'iyyeye mahsus odada ma'kud meclis-i şeri'de 5 Muharrem 1324/1 Mart 1906 tarihli vakfiyesini kaydettiren Abdullah bin Hüseyin hâkimin önünde vakfın mütevellisi ile davalaşır. Abdullah, vakfettiği bağdaki ağaçların menkul hükmünde olduğunu, menkulün vakfının ise caiz ve sahih olmadığını ifade ederek vakfından rücû etmek istediğini belirtir. Vakfın mütevellisi ise söz konusu ağaçların menkul olduğunu, ancak İmâm Muhammed'e göre mevkûf arsa üzerine dikilen ağaçların arsaya tabi olduğunu, dolayısıyla menkulün caiz olduğunu belirtir. Bu tür durumlarda hayırda ittihadın esas alınması gerektiğini, İmâm Muhammed ve Ebû Yusuf'a göre mevkûf mütevelliye teslim edildikten sonra vakfın sahih ve lâzım (bağlayıc1) olduğunu ve vakıftan geri dönüşün mümkün olamayacağını dile getirir. Her iki tarafın delillerini dinleyen Kadı, vakfı teşyid etmenin (sağlamlaştırmanın) daha evla olduğuna kanaat ederek vakfın sıhhatine ve vakıfta rücûun olamayacağına karar verir. ${ }^{121}$ Böylece hâkim, menkulün vakfının caiz olmadığını ifade eden İmâm-ı Âzam'ın fetvasını değil menkulün vakfını caiz gören İmâm Muhammed ve Ebû Yûsuf'un fetvasinı uygular.

\footnotetext{
120 Mergīnānī, el-Hidāye, 3/17; Mehmet Dirik, "Ebû Hanîfe'nin İctihad Metodunda İstihsan", PAU İlahiyat Fakültesi Dergisi 5/10 (2018), 216.

121 VGMA, Defter 603/179/302.
} 
482 | H. TELLİ / Osmanlı Vakıf Belgelerinde İmâm-1 Âzam Ebû Hanîfe ve Görüşleri: Makedonya Vakfiyeleri Örneği

\subsection{Vakf-1 Nukûd İle İlgili Görüşü}

Hanefi fıkıh kitaplarında nukûd yani para vakfının caiz olmadığ1 ifade edilmektedir. İmâm-1 Âzam'a göre menkulün vakfı caiz olmadığ ${ }^{122}$ için para vakfı da caiz değildir. Ancak İmâm Züfer'in para vakfını caiz gördüğü nakledilmektedir. ${ }^{123}$ Osmanlı ulemasından Şeyhülislâm Ebussuud Efendi ve Kemal Paşa-zade para vakfının caiz olduğunu savunmuşlardır. ${ }^{124}$

Makedonya'da vakıf hizmetleri sunan birçok vâkıfın para vakfında bulunduğu görülmektedir. Para vakfını içeren vakfiyelerin bazılarında ise para vakfının sıhhati ve geçerliliği konusu ele alınmış ve tartışılmıştır. Bu tartışma zemini vakıftan rücu davasının yer aldığı vakfiyenin son kısmında kendini göstermiştir.

Makedonya vakfiyelerinde vâkıflar, vakf-1 nukûdun İmâm-1 Âzam, Ebû Yûsuf ve İmâm Muhammed nazarında gayr-i sahih ve batıl olduğunu, bu yüzden vakıflarından rücû etme haklarına sahip olduklarını ifade ederek vakıflarından rücû etmek istemişler ve vakfettikleri parayı tekrar geri almak için vakfın mütevellisi ile meclis-i şer'ide davalaşmışlardır. Mütevelliler ise İmâm Züfer katında vakf-1 nukûdun sahih olduğunu söyleyerek mevkuf parayı vâkıflara vermekten imtina etmişlerdir. Tarafların delillerini dinleyen hâkim ise vakf-1 nukûdun sahih ve lâzım olduğuna ve rücûun mümkün olamayacağına karar vermiştir. Makedonya vakfiyelerinde vakf-ı nukûd ile ilgili davalaşmanın farklı yüzyıllarda nasıl cereyan ettiği ile ilgili birkaç örnek vermek istiyoruz.

Rumeli Vilayeti kaymakamlarından Ali Ağa bin Abdullah, Manastır'da Cami-i Cedid avlusunda müceddeden bir kütüphane yaptırmış ve iki yüz kuruşluk kazanç getiren akçesini bu kütüphanenin hâfız-1 kütüb olan görevlisinin maaşı ve kütüphanenin tamiri gibi ihtiyaçları için vakfetmiştir. 1 Rebiü'l-evvel 1185/14 Haziran 1771 tarihli vakfiyesinde Ali Ağa, meclis-i şer'ide vekili Said Efendi vasıtasıyla para vakfının İmâm-ı Âzam'ın da olduğu eimme-i selâse (üç büyük İmâm) katında gayr-i sahih olduğunu ve zımnında olan şartların dahi câiz

\footnotetext{
122 Mergīnānī, el-Hidāye, 3/17.

123 Ahmet Akgündüz, İslam Hukukunda ve Osmanlı Tatbikatında Vakıf Müessesesi (İstanbul: OSAV Yayınları, 1996), 218.

124 Yakup Ahbab, "Kalkandelen Para Vakıfları”, Osmanlı Medeniyeti Araştırmaları Dergisi 5/5 (2017), 53.
} 
H. TELLİ / Al-Imam al-A'zam Abu Hanifa and His Views in Ottoman Foundation Documents: Example of Macedonia Waqfiyyas | 483 olmadığını ifade ederek vakfından rücû etmek istediğini beyan eder ve parasının kendisine tekrar geri verilmesini ister. Vakfın mütevellisi Ahmed Efendi ise bundan imtina eder. Taraflar arasındaki davaya bakan hâkim ise İmâm Züfer'den mervî olan İmâm Muhammed bin Abdullah el-Ensârî'nin kavl-i şerifine göre para vakfının sahih ve İmâmeyne (Ebû Yusûf ve İmâm Muhammed'e) göre vâkıfın vakfettim demesiyle ve mevkûfunu mütevelliye teslim etmesiyle vakfın sahih ve lâzım olduğunu ifade ederek vakfın sıhhatine ve lüzûmuna hükmeder. ${ }^{125}$

Manastır vilayetinin Debre Sancağı dâhilinde Rekalar kazasına tabi Velobrde (Volobrodya) köyünden Hatib Ağa b. İbrahim, köyün ortasına bir cami yaptırır ve bu cami için tahmini olarak bir dönüm tutarındaki meyve bahçesini, bir dönümlük bağını ve 6600 kuruş parasını vakfeder. Buralardan elde edilecek gelirin caminin imam ve hatibinin maaşının karşılanması ve caminin tamir ihtiyaçları için harcanmasını şart koşar. 21 Receb 1829/18 Temmuz 1911 tarihli vakfiyesinde vâkıf, yapmış olduğu vakf-ı nukûdun ve ona bağlı şartların eimme-i selâse yani İmâm-1 Âzam Ebû Hanife, Ebû Yusuf ve İmâm Muhammed nazarında sahih olmadığını, yine yaptığı vakf-1 akârın İmâm-1 Âzam katında sahih ancak gayr-i lâzım olduğunu ifade ederek vakfından rücû etmek istediğini belirtir. Vakfın mütevellisi ise:

"Lākin İmām Züfer Hażretlerinden İmām Muhammed bin 'Abdullah el-Ensārī

Ḥażretlerinin rivayeti üzerine vakf-ı nukūd ve ona mutedạrrı olan şurūṭ ve kuyūd șahịḥ

olduğu gibi bāğ ve bahçe-i mežkūrun dahī vaḳfiyyeti caiz olmağla redd ü teslimden imtinā' ederim"'126

diyerek İmâm-ı Züfer'e göre para vakfının ve buna bağlı şartların sahih ve hukuken bağlayıcı olduğunu, bu yüzden vakıftan rücûun mümkün olamayacağını ve mevkûfu vâkıfa geri teslim etmeyeceğini beyan eder. Tarafların delillerini dinleyen hâkim de "mubțil-i hayr olmaktan hazer" ederek bu konuda daha önce hüküm veren müçtehitlere tabi olarak mezkûr bağ, bahçe ve nukûda ait vakfın sahih ve şartlarının da câiz olduğuna karar verir. Böylece hâkim, vakf-1 nukûdla ilgili olarak İmâm-1 Âzam'ın da dâhil olduğu eimme-i selâse'ye göre değil İmâm Züfer'in fetvasına göre amel etmiş olur. ${ }^{127}$

\footnotetext{
125 VGMA, Defter 652-2/127/254.

126 VGMA, Defter 604/146/197.

127 VGMA, Defter 604/146/197.
} 
484 | H. TELLİ / Osmanlı Vakıf Belgelerinde İmâm-1 Âzam Ebû Hanîfe ve Görüşleri: Makedonya Vakfiyeleri Örneği

Kaçanikli Mehmed Paşa, Üsküp ve civarında sahip olduğu çiftliklerini, tarlalarını, bağlarını, çayırlarını, bahçelerini, değirmenlerini, kahvehanesini, fırınlarını, dükkânlarını ve Kâtip Şahin Mahallesi'nde yaptırdığı konağının yanı sıra 10.000 altın (1.250.000 akçe) parasını da vakfeder. Şaban 1017/ Kasım 1608 tarihli bir vakfiyesinde Kaçanikli Mehmed Paşa, nukûd vakfının İmâm-1 Âzam Ebu Hanife'nin fetvasına göre batıl olduğunu gerekçe göstererek nukûd vakfından rücû etmek istediğini ifade eder ve bu konuda vakfın mütevellisi ile meclis-i şer'de davalaşır. Vakfın mütevellisi Ahmet Çavuş ise itiraz ederek İmâm-1 Râbi İmâm Züfer katında vakf-1 nukûdun sahih olduğunu ve meblağın kendisine teslim edildikten sonra vakıftan rücûun olamayacağını ifade eder. Tarafların delillerini dinleyen hâkim vakfı kurmanın, devam ettirmenin ve güçlendirmenin daha evla olduğuna kanaat getirerek vakf-1 nukûdun (para vakfının) sahih olduğuna ve rücûun mümkün olamayacağına hükmeder. Hâkim böylece para vakfının sıhhati ve bağlayıcılığı konusunda İmâm-ı Âzam'ın fetvasını değil İmâm Züfer'in fetvasinı uygular. ${ }^{128}$

Üsküp'ün Batince köyündeki cami için 1000 kuruş vakfeden Bayram bin Zeynel'in 29 Rebiü'l-ahir 1324/22 Haziran 1906 tarihli vakfiyesinde, ${ }^{129}$ Üsküp'te Arnavut köyündeki cami için 1000 kuruşunu vakfeden Felek bin Bahaeddin bin Ömer'in 19 Safer 1317/29 Haziran 1899 tarihli bir vakfiyesinde, ${ }^{130}$ aynı köydeki cami için 2000 kuruşunu vakfeden Memiş bin Osman'ın 9 Cemaziye'l-ahir 1311/18 Aralık 1893 tarihli vakfiyesinde ${ }^{131}$ ve Üsküp'ün İstemiçe köyündeki cami için 2000 kuruşunu vakfeden Osman bin Latif'in 8 Cemaziye'l-âhir 1327/27 Haziran 1909 tarihli vakfiyesinde vâkıflar, meclis-i şer'ide "eimme-i selâse nezdinde nukûd vakfı batıldır" diyerek vakıflarından rücû etmek istediklerini ifade etmişler ve bu konuda vakfın mütevellileri ile davalaşmışlardır. Vakfın mütevellileri ise "İmām Züfer rahmetu'llāhi 'aleyh Ḥażretlerinden İmām 'Abdullahi'l-Enșāiri rivāyeti üzere vaḳf-1 nuḳūd ve ẓımnında olan şurūṭ ve ḳuyūdun sı̣̣hati muḳarrer"132 diyerek nukûd vakfın imam Züfer'e göre sahih olduğunu ve rücûun mümkün

\footnotetext{
128 VGMA, Defter 633/21/11.

129 VGMA, Defter 601/155/199.

130 VGMA, Defter 989/165/123.

131 VGMA, Defter 989/164/122.

132 VGMA, Defter 991/33/37.
} 
H. TELLİ / Al-Imam al-A'zam Abu Hanifa and His Views in Ottoman Foundation Documents: Example of Macedonia Waqfiyyas I 485 olamayacağını ve bu sebeple kendilerine teslim edilen vakıf paralarını vâkıflara geri vermeyeceklerini ifade etmişlerdir. Her üç davada da hâkim nukûd vakfının sıhhatine ve lüzûmuna karar vererek vakıfta rücûu reddeder. Böylece İmâm-1 Âzam'ın fetvasını değil İmâm Züfer'in fetvasinı esas alır. ${ }^{133}$

Vakf-1 nukudla ilgili davalar benzer şekilde Makedonya'daki şu vakıflarda da ele alınmıştır.

- Manastır'da Hacı Mehmed bin İbrahim Vakfı: Vâkıf, Yeni Camii' de ta'lim-i ilim yapan muallimin maaşının karşılanması için sahip olduğu 600 kuruşunu vakfeder. (Vakfiyenin tarihi: 1 Muharrem 1177/12 Temmuz 1763). ${ }^{134}$

- Kumanova'da Şakir Ağa bin Arslan Vakfı: Vâkıf, 1500 kuruşunu vakfeder. Mevkuf nukûddan elde edilen geliri Bektaşlı Bâlâ köyünde Hasan Hoca bin Abdullah tarafından ihya ve inşa edilen caminin imam ve hatibinin maaşının karşılanması, gerektiğinde caminin tamirinin yapılması ve kandil ihtiyacının giderilmesi için tahsis eder. (Vakfiyenin tarihi: 25 Safer 1322/11 Mayıs 1904). ${ }^{135}$

- Kalkandelen'in Lekboş köyünden Salih bin Elmas Vakfı: Vâkıf, sahip olduğu 1000 kuruşunu mezkûr köydeki caminin imâmet cihetine meşrûta olmak üzere Allah rızası için vakfeder. (Vakfiyenin tarihi: 5 Safer 1310/29 Ağustos 1892). ${ }^{136}$

- Debre'nin Ketuce köyünden Abdurrahman b. Hüseyin Vakfi: Vâkıf, sahip olduğu 800 kuruşunu köyde ahali tarafından yaptırılan caminin imam ve hatiplik cihetine harcanmak üzere vakfeder. (Vakfiyenin tarihi: 3 Şaban 1314/7 Ocak 1897). ${ }^{137}$

- Debre'de Kocacık köyünde Murad bin Yusuf Vakfı: Vâkıf, sahip olduğu bir bâb dükkânını ve 3000 kuruşunu vakfeder. Mevkufun gelirini de köyde inşa ettiği caminin imam ve hatiplerin maaşı için tahsis eder. (Vakfiyenin tarihi: 27 Şaban 1313/12 Şubat 1896). ${ }^{138}$

- Debre'de Ustuşas köyünde Hayreddin bin Abdurrahman Vakfı: Vâkıf, sahip olduğu 500 kuruşunu Allah rızası için vakfeder.

\footnotetext{
133 VGMA, Defter 991/33/37.

134 VGMA, Defter 626-2/714/737.

135 VGMA, Defter 989/226/179.

136 VGMA, Defter 989/167/126.

137 VGMA, Defter 989/167/126.

138 VGMA, Defter 990/47/38.
} 
486 | H. TELLİ / Osmanlı Vakıf Belgelerinde İmâm-1 Âzam Ebû Hanîfe ve Görüşleri: Makedonya Vakfiyeleri Örneği

Mevkûf paradan elde edilen gelirin köyde ahalinin yaptırdığı caminin imam ve hatip cihetine harcanmasını arzu eder. (Vakfiyenin tarihi: 4 Cemâziye'l-âhir 1314/10 Kasım 1896). ${ }^{139}$

Para vakfının sıhhati ve geçerliliği konusunu ele alan tüm vakfiyeler değerlendirildiğinde İmâm-ı Âzam'ın para vakfını câiz görmediğiyle ilgili fetvasının vakıftan rücu davası kapsamında gündeme geldiği ve bu konudaki fetvasının uygulanmadığı tespit edilmiştir. Hâkimler bu konuda para vakfını câiz gören İmâm Züfer'in görüşüyle amel etmişler ve para vakfının sahih ve lâzım olduğuna hükmetmişlerdir. Ancak şurası da vardır ki İmâm-ı Âzam'ın fetvası zahiren uygulanmıyor gibi gözükse de onun fetvası vakfın te'bidi ve teşyidi açısından çok önemli bir araç olarak kullanılmıştır. Zira vâkıflar, İmâm-1 Âzam'ın fetvasını uygulamamak için değil vakıftan rücû davasının bir daha gündeme gelmesini engellemek, vakfı ebedî kılmak ve güçlendirmek amacıyla onun fetvasını vakfiyede dile getirmişlerdir.

\section{Sonuç}

Osmanlılar, 1390 yılında Makedonya coğrafyasına hâkim olduktan sonra fethedilen diğer yerlerde olduğu gibi burada da vakıf hizmetleri sunmuştur. Bu anlamda Makedonya'nın Üsküp, Debre, Doyran, Eğri Palanka, Gostivar, İştip, Kalkandelen, Koçani, Köprülü, Kratova, Kumanova, Manastır, Ohri, Pirlepe, Tikveş ve Ustrumca gibi şehirlerinde vakıflar kurulmuş, bunlara ait vakfiyeler düzenlenmiş ve bu vakfiyelerin birçoğu günümüze kadar korunmuştur. Bu vakfiyelerin bir kısmında Hanefi mezhebinin kurucusu İmâm-1 Âzam Ebû Hanîfe'ye ve görüşlerine yer verildiği görülür. $\mathrm{Bu}$ çalışmada Makedonya coğrafyasında kurulan vakıflarla ilgili tespit edilebilen 164 vakfiye incelenmiş ve 64 vakfiyede konuyla ilgili bilgilere ulaşılmıştır. Vakfiyelerde, vakıf hizmetleri sunan kişilerin zihin dünyasında nasıl bir İmâm-1 Âzam tasavvuru bulunduğu ve onun hangi görüşlerinin vakfiyelere neden ve nasıl yansıdığı konusunda önemli detaylar tespit edilmiştir.

Vakfiyelerde İmâm-1 Âzam'ın İslâm dünyasının kadim, civanmert, önde gelen, şerefli, değerli ve en büyük âlimlerden biri olduğuna, içtihat konusunda üstün bir makamda bulunduğuna, hidayeti ve doğru yolu bulmada insanlara imamlık ve rehberlik ettiğine ve ümmetin yolunu

139 VGMA, Defter 605/137/194. 
H. TELLİ / Al-Imam al-A'zam Abu Hanifa and His Views in Ottoman Foundation Documents: Example of Macedonia Waqfiyyas | 487 aydınlatan bir kandil olduğuna özellikle vurgu yapılmıştır. İsmi hayır, hürmet ve tazimle anılmış ve kendisine dualar edilmiştir. İmâm-1 Âzam'la ilgili bu tasavvurun Bektaşî tekkelerinde de olduğu tespit edilmiştir.

Vâkıflar, vakfı İmâm-1 Âzam'ın tanımlamasına uygun olarak tanımlamışlardır. Makedonya vakfiyelerinin hemen hemen hepsinde "vakf" kelimesinin İmâm-1 Âzam'ın görüşüne uygun olarak "habs" manasında kullanıldığı tespit edilmiştir

İmâm-1 Âzam'in görüşlerine vakfiyelerin son kısımlarında bulunan vakıftan rücû davasının yer aldığı bölümlerde yer verildiği görülmüştür. Vâkıfın vakfından geri dönmek, vazgeçmek ve vakfını iptal etmek amacıyla meclis-i şer'ide kadının huzurunda vakfın mütevellisine karşı açtığı davalara rücû davası denmiştir. Bu davada vakfın sahih ve/veya lâzım (hukuken bağlayıcı) olmadığını savunan ve bu yüzden vakfından rücû etmek istediğini ifade eden vâkıf, İmâm-1 Âzam'ın bazı görüşlerini kendi lehinde delil olarak sunmuştur. Vakıftan rücûun olamayacağını savunan vakfın mütevellisi ise Ebû Yûsuf, İmâm Muhammed ve İmâm Züfer' in fetvalarını delil olarak getirmiştir.

Vâkıf ve mütevelli arasında cereyan eden rücû davalarında vakfın sıhhati ve lüzumu, vakf-1 akâr, vakf-1 menkul ve vakf-1 nukûdla ilgili konularda tartışmalar yaşanmıştır. İmâm-ı Âzam’ın vakfın sıhhati ve lüzumu konusundaki fetvası vakfiyelerde "vaḳfın sıhhati lüzûmunu müstelzim kılmaz" şeklinde ve onun vakf-1 akâr konusundaki fetvası "vaḳf-1 'aḳār İmām-1 A'ẓam ḳatında menzile-i 'āriyette olmağla rücū'u meşrû" şeklinde formüle edilerek dile getirilmiştir. İmâm-1 Âzam'ın görüşlerini bu formatta kendi lehine delil olarak getiren vâkıf, vakf-1 akârın ödünç konumunda olduğunu, vakfettiği akârın kendi mülkünden çıkmadığını, vakfın sahih olsa da lâzım olamayacağını, bu yüzden vakfından rücû etmek hakkına sahip olduğunu ifade ederek vakfından geri dönmek istediğini beyan etmiştir. Vâkıf, vakf-1 menkul ve vakf-1 nukûdu caiz görmeyen İmâm-1 Âzam'ın görüşünü delil göstererek vakfettiği menkul ve paraları geri almak istemiştir. Vakfın mütevellileri ise Ebû Yûsuf, İmâm Muhammed ve İmâm Züfer'in fetvalarını delil getirerek bu rücûun mümkün olamayacağını savunmuşlardır. Tarafların delillerini dinleyen hâkim de verdiği tüm kararlarda İmâm-1 Âzam'ın değil Ebû Yûsuf, İmâm Muhammed ve İmâm Züfer'in fetvalarına uyarak vakfın sahih ve lâzım olduğuna ve 
488 | H. TELLİ / Osmanlı Vakıf Belgelerinde İmâm-1 Âzam Ebû Hanîfe ve Görüşleri: Makedonya Vakfiyeleri Örneği

vakfın devamına karar vermiştir. Vâkıfın aleyhine sonuçlanan bu davaların aslında vâkıf tarafından bile bile açıldığı, fikri planda mizansen ve kurgusal, ancak hukuki açıdan bağlayıcı olan davalar olduğu anlaşılmıştır. Vâkıfın, geri dönüşü mümkün olmayacak şekilde vakfını daha da sağlamlaştırmak, daha sonradan gerek kendisi gerekse mirasçıları tarafından rücû davasının açılmasını önlemek ve rücû davası konusunu bir daha gündeme getirmemek amaciyla bu tür davalara vakfiyesinde bilinçli bir şekilde yer verdiği tespit edilmiştir. Dolayısıyla vakfiyelerde İmâm-1 Âzam'ın görüşlerinin, uygulanmak amacıyla değil vakfı ebedî kılmanın, vakfı sağlamlaştırmanın ve vakıftan geri dönüşü engellemenin bir aracısı olarak gündeme getirildiği ve ön plana çıkartıldığı sonucuna varılmıştır. İmâm-ı Âzam'ın görüşlerinin Osmanlı vakıf tatbikatında vakfın ebedîliği ve güçlendirilmesi konusunda çok önemli bir rol üstlendiği sonucuna ulaşılmıştır.

\section{Kaynakça}

\section{Kitap ve Makale}

Abdülbâkî, Muhammed Fuâd. el-Mu'cemü'l müfehres li elfâzi'l-Kur'âni'lKerîm. İstanbul: Çağrı Yayınları, 1987.

Ahbab, Yakup. "Kalkandelen Para Vakıfları". Osmanlı Medeniyeti Araştırmaları Dergisi 5/5 (2017), 49-71.

Ak, Ahmet. "İmâm-1 Azâm Ebû Hanife'nin Hayatı ve İtikadî Görüşleri”. KSÜ İlahiyat Fakültesi Dergisi 27 (2016), 1-28.

Akdağ, Eyüp. "Ebû Hanîfe'nin (ö.150/767) Hayatı ve Zühd Anlayışı". Amasya Üniversitesi İlahiyat Fakültesi Dergisi 11 (2018), 159-176.

Akgündüz, Ahmet. İslam Hukukunda ve Osmanl Tatbikatında Vakıf Müessesesi. İstanbul: OSAV Yayınları, 1996.

Ali Haydar Efendi, Eminefendizâde Küçük (ö. 1935). Tertîbu's-Sünûf fi Ahkâmi'l-Vukûf. Dersaadet: 1339-1340/1920-1921.

Arslan, Ramazan. Erzurum Şehir Merkezindeki Vakıflar ve Sosyo-Ekonomik Bir Değerlendirme. Erzurum: Atatürk Üniversitesi, Sosyal Bilimler Enstitüsü, Yüksek Lisans Tezi, 1995.

Başbakanlık Osmanlı Arşivi Daire Başkanlığı (BOA). Makedonya'daki Osmanlı Evrakı. Ankara: Osmanlı Arşivi Daire Başkanlığı Yayınları, 1996.

Çataltepe, Sipahi. İslam-Türk Medeniyetinde Vakıflar. İstanbul: Türkiye Milli Kültür Vakfı Yayınları, 1991. 
H. TELLİ / Al-Imam al-A'zam Abu Hanifa and His Views in Ottoman Foundation Documents: Example of Macedonia Waqfiyyas I 489

Dirik, Mehmet. “Ebû Hanîfe'nin İctihad Metodunda İstihsan”. PAU Ilahiyat Fakültesi Dergisi 5/10 (2018), 180-224.

Döndüren, Hamdi. “İslam'da Vakıf ve Güncel Değeri”. Keşkül Dergisi 38 (2016), 21-26.

Ertem, Adnan. “Osmanlıdan Günümüze Vakıflar”. Vakıflar Dergisi 36 (2011), 25-65.

Hacısalihoğlu, Mehmet. "Makedonya". Türkiye Diyanet Vakfi İslâm Ansiklopedisi. 27/437-444. Ankara: TDV Yayınları, 2003.

Halaçoğlu, Yusuf. "Osmanlılarda Vakıf Müessesesi". Vakıf Haftası Dergisi 1 (1984), 98-99.

İmâmoğlu, Hüseyin Vehbi. Bir Dünya Devleti Osmanlı (1299-1922). Samsun: Ceylan Ofset, 2008.

İnalcık, Halil. Devlet-i Aliyye Osmanlı Imparatorluğu Üzerine Araştırmalar1. 2 Cilt. İstanbul: Türkiye İş Bankası Kültür Yayınları, 2009.

İnbaşı, Mehmet. "Balkanlar'da Osmanlı Hakimiyeti ve İskan Siyaseti”.

Türkler. ed. Hasan Celal Güzel vd.. 9/279-301. Ankara: Yeni Türkiye Yayınları, 2002.

Kosova Vilayeti Salnamesi. Kosova: y.y., 1304. Erişim Tarihi: 11 Temmuz 2020. file://C:/Users/hzhgt/Downloads/D02460130400000004.pdf.

Koyunoğlu, H. Hüsnü. Sosyal Politika Açısından Vakıflar. İstanbul: İstanbul Üniversitesi, Sosyal Bilimler Enstitüsü, Doktora Tezi, 2002.

Köprülü, Fuat. "Vakıf Müessesesinin Hukuki Mahiyeti ve Tarihi Tekâmülü". Vakıflar Dergisi 2 (1942), 1-35.

Köse, Murtaza. "Büyük Üstad Ebû Hanîfe". A ̆ğr İbrahim Çeçen Üniversitesi Sosyal Bilimler Enstitüsü Dergisi 1/1 (2015), 159-176.

Kubbeatlı Akademisi Kültür ve Sanat Vakfı. "Kubbealtı Lugatı". Erişim tarihi: 27 May1s 2020. http://www.lugatim.com/.

Kur'ân-1 Kerîm Meâli. çev. Halil Altuntaş - Muzaffer Şahin. Ankara: Diyanet İşleri Başkanlığ Yayınları, 2011.

Mergīnānī, Ebü'l-Hasen Burhânüddîn Alî b. Ebî Bekr b. Abdilcelîl elFergānî. el-Hidāyetü şerḥu Bidāyeti'l-Mubtedī. thk. Muhammed Adnân Dervîş. 4 Cilt. Beyrut: Şeriketü Dâri'l-Erkâm, ts.

Ömer Hilmi Efendi (Karînabâdîzâde) (ö. 1307/1889). İthâfü'l-Ahlâf Fî Ahkâmi'l-Evkâf. İstanbul: Matbayı Amire, 1307.

Özgüdenli, Osman Gazi. "Vakfiye". Türkiye Diyanet Vakfi İslâm Ansiklopedisi. 42/465-467. İstanbul: TDV Yayınları, 2012. 
490 I H. TELLİ / Osmanlı Vakıf Belgelerinde İmâm-1 Âzam Ebû Hanîfe ve Görüşleri: Makedonya Vakfiyeleri Örneği

Sâğircî, Esad Muhammed Said. Delilleriyle Hanefi Fıkhı. çev. Halil Aldemir vd.. İstanbul: Karınca\&Polen Yayınları, 2009.

Sarı, Mevlüt. El-Mevarid Arapça-Türkçe Lugat. İstanbul: Bahar Yayınları, 1984.

Serahsî, Ebû Bekr Şemsü'l-eimme. Kitâbu'l-Mebsût. Beyrut: Dâru'lMa'rife, ts.

Şafak, Ali. "Akar". Türkiye Diyanet Vakfi İslâm Ansiklopedisi. 2/221. İstanbul: TDV Yayınları, 1989.

Telli, Hasan. Osmanlı Dönemi Üsküp Vakıfları. Ankara: İlahiyat Yayınları, 2019.

Telli, Hasan. “Osmanlı Döneminde Üsküp Vakfiyelerinde Görülen Vakıftan Rücû' Davaları ve Fıkhi Meseleler". Uluslararası Sosyal Araştırmalar Dergisi 11/55 (2018), 1043-1058.

Vakıflar Genel Müdürlüğü. "Vakıf Deyimleri ve Terimleri Sözlü̆̆̈̈̈. Erişim Tarihi: $03 \quad$ Temmuz 2020.

https://www.vgm.gov.tr/kurumsal/tarihce/vakif-deyimleri-veterimleri-sozlugu\#dic26.

Uzunçarşılı, İsmail Hakkı. Osmanlı Tarihi I. 4 Cilt. Ankara: TTK Yayınları, 1984.

Uzunpostalcı, Mustafa. "Ebû Hanîfe". Türkiye Diyanet Vakfi İslâm Ansiklopedisi. 10/131-138. İstanbul: TDV Yayınları, 1994.

Yeniçeri, Celal. "Ebû Hanîfe'nin Hayatı, Malî ve İktisadî Görüşleri". Marmara Üniversitesi İlahiyat Fakültesi Dergisi 4 (1986), 255-272.

Yıldız, İbrahim. Kur'ân'da Sebîlüllah Kavramı. Bursa: Emin Yayınları, 2015.

Yılmaz, Yasin, "Vakıf Kurumunun Dayandığı Temel Referanslar ve Zürrî Vakıfların Vakıf Sistemindeki Yeri". Dinî Araştırmalar 17/44 (2014), 43-66.

Yılmaz, Yasin. Kanunî Vakfiyesi ve Süleymaniye Külliyesi. Ankara: Vakıflar Genel Müdürlüğ̈̈ Yayınları, 2008.

Yılmaz, Yasin - Aydemir, Hilal. Erzurum Şeyhler Vakfı ve Külliyesi. Ankara: Semih Ofset, 2019.

Yilmaz, Yasin. Örfizâde Vakfı. Ankara: Semih Ofset, 2012. 
H. TELLİ / Al-Imam al-A'zam Abu Hanifa and His Views in Ottoman Foundation Documents:

\section{Osmanlı Arşiv Belgeleri}

Example of Macedonia Waqfiyyas | 491

\subsection{Devlet Arşivleri Genel Müdürlüğü Osmanlı Arşivleri Daire}

\section{Başkanlığı (BOA)}

BOA, AE.SABH.I.56-3994

BOA, A.DVNSMHM.D.85-439

BOA, AE.SABH.I.107-7308

BOA, AE.SMST.II.9-806

BOA, A.DVNSHM.D.91-263

BOA, AE.SSLM.III.34-1949

BOA, AE.SMST.III.44-3155

BOA, DH.ID.16-43

BOA, C.EV.63-3145

BOA, AE.SMMD.IV.81-9616

BOA, C.BLD.18-851

BOA, C.EV.66-3282

BOA, C.EV.67-3335

BOA, C.EV.85-4207

BOA, C.EV.120-5983

BOA, C.EV.69-3426

BOA, C.EV.251-12641

BOA, C.EV.50-2452

BOA, C.EV.461-23309

BOA, C.EV.118-5885

BOA, C.EV.132-6581

BOA, EV.BRT.5-13

BOA, EV.BRT.1-16

BOA, EV.BT.143-10

BOA, EV.BRT.41-13

BOA, EV.BRT.212-9

BOA, EV.BRT.199-23

BOA, İE.EV.21-2529

BOA, EV.D.14487

BOA, İ.ŞD.68-3984

BOA, HR.SFR.04..710-59

BOA, İ.ML.91-29

BOA, İ.EV.55-23

BOA, MVL.472-21

BOA, MVL.467-90

BOA, TFR.I.ŞKT.64-6389

BOA, TFR.I.MN.185-18410

BOA, TFR.I.ŞKT.47-4625

BOA, TFR.I.ŞKT.119-11843

BOA, Y.A.RES.94-21

BOA, TFR.I.ŞKT.16-1507

BOA, HAT.1604-68

BOA, TFR.I.KV.75-7425

BOA, TFR.I.KV.133-13228

BOA, İÇMMS.20-890

\subsection{Vakıflar Genel Müdürlüğü Arşivi (VGMA)}

VGMA, Defter 582-2/373/280

VGMA, Defter 583/146/129

VGMA, Defter 582-2/503/376

VGMA, Defter 597/89/59

VGMA, Defter 601/155/199

VGMA, Defter 597/81/47

VGMA, Defter 603/179/302

VGMA, Defter 600/262/328

VGMA, Defter 601/157/204

VGMA, Defter 604/145/196

VGMA, Defter 604/138/183

VGMA, Defter 604/146/197

VGMA, Defter 605/137/194

VGMA, Defter 607/44/65

VGMA, Defter 609/253/305

VGMA, Defter 626-2/714/737

VGMA, Defter 929/3/3

VGMA, Defter 629/415/332

VGMA, Defter 629/423/333

VGMA, Defter 629/736/489 
492 | H. TELLI / Osmanlı Vakıf Belgelerinde İmâm-1 Âzam Ebû Hanîfe ve Görüşleri: Makedonya Vakfiyeleri Örneği

VGMA, Defter 630/1338/816

VGMA, Defter 632/424/194

VGMA, Defter, 633/348/123

VGMA, Defter 652-2/615/653

VGMA, Defter 987/199/63

VGMA, Defter 988/142/56

VGMA, Defter 988/259/162

VGMA, Defter 988/286/184

VGMA, Defter 989/63/51

VGMA, Defter 989/150/114

VGMA, Defter 989/165/123

VGMA, Defter 989/170/127

VGMA, Defter 989/180/137

VGMA, Defter 989/226/179

VGMA, Defter 989/235/186

VGMA, Defter 990/3/3

VGMA, Defter 990/48/39

VGMA, Defter 990/74/62

VGMA, Defter 990/91/77

VGMA, Defter 991/24/26

VGMA, Defter 991/45/57

VGMA, Defter 991/58/75
VGMA, Defter 631/25/10

VGMA, Defter 633/21/11

VGMA, Defter 652-2/127/254

VGMA, Defter 987/94/22

VGMA, Defter 987/274/95

VGMA, Defter 988/237/144

VGMA, Defter 988/278/177

VGMA, Defter 989/50/39

VGMA, Defter 989/122/86

VGMA, Defter 989/164/122

VGMA, Defter 989/167/126

VGMA, Defter 989/174/132

VGMA, Defter 989/185/141

VGMA, Defter 989/234/185

VGMA, Defter 989/244/190

VGMA, Defter 990/47/38

VGMA, Defter 990/53/47

VGMA, Defter 990/77/65

VGMA, Defter 990/156/154

VGMA, Defter 991/33/37

VGMA, Defter, 991/53/70

VGMA, Defter 991/59/76 